\author{
RESEARCH ARTICLE \\ 10.1029/2019TC005754 \\ Key Points: \\ - Fission track and fault kinematic \\ data document horizontal and \\ vertical motions of fault-bound \\ crustal blocks in the eastern Eastern \\ Alps \\ - Diachronous Late Cretaceous to \\ Paleocene fast cooling of \\ Austroalpine units was followed by \\ slow Eocene-Oligocene cooling \\ - The Mur-Mürz fault did not \\ accommodate significant \\ differential vertical motions during \\ and after the extrusion of the Styrian \\ block
}

Correspondence to:

E. Willingshofer,

e.willingshofer@uu.nl

Citation:

van Gelder, I. E., Willingshofer, E., Andriessen, P. A. M., Schuster, R., \& Sokoutis, D. (2020). Cooling and vertical motions of crustal wedges prior to, during and after lateral extrusion in the Eastern Alps: new field kinematic and fission track data from the Mur-Mürz fault system. Tectonics, 39, e2019TC005754. https://doi.org/ 10.1029/2019TC005754

Received 10 JUL 2019 Accepted 8 FEB 2020

Accepted article online 12 FEB 2020

(C)2020. The Authors.

This is an open access article under the terms of the Creative Commons Attribution License, which permits use, distribution and reproduction in any medium, provided the original work is properly cited.

\section{Cooling and Vertical Motions of Crustal Wedges Prior to, During, and After Lateral Extrusion in the Eastern Alps: New Field Kinematic and Fission Track Data from the Mur-Mürz Fault System}

\author{
I. E. van Gelder, ${ }^{1,2}$, E. Willingshofer ${ }^{1}$ (D) P. A. M. Andriessen ${ }^{3}$, R. Schuster ${ }^{4}$ (D), \\ and D. Sokoutis ${ }^{1}$ iD \\ ${ }^{1}$ Faculty of Geosciences, Utrecht University, Utrecht, The Netherlands, ${ }^{2}$ Now at Inpijn-Blokpoel Ingenieurs, Son, The \\ Netherlands, ${ }^{3}$ Faculty of Earth and Life Sciences, VU-Amsterdam, Amsterdam, The Netherlands, ${ }^{4}$ Geological Survey of \\ Austria, Vienna, Austria
}

\begin{abstract}
New structural and thermochronological (zircon and apatite fission track) data from the eastern most Alps highlight distinct deformation phases affecting the Austroalpine unit along a major sinistral strike-slip fault system, the Mur-Mürz fault (MMF). The data link deformation to vertical motions prior to, during, and after the main phase of lateral extrusion of the orogen. Zircon fission track ages document rapid (ca. $15^{\circ} \mathrm{C} / \mathrm{Myr}$ ) and diachronous (eastward younging) cooling and rock exhumation during the latest Cretaceous to Paleocene. Subsequent regional Eocene to early Miocene cooling below the closure temperature of the apatite fission track system occurred at slow rates (ca. $2^{\circ} \mathrm{C} / \mathrm{Myr}$ ), suggesting that the region was not subject to major surface uplift and erosion during that period. Fault kinematic analysis along the MMF document pre-extrusion NNW-SSE contraction, middle Miocene syn-extrusion NE-SW to NNE-SSW directed shortening, and Late Miocene E-W contraction. All phases are characterized by strike-slip fault regimes. Formation of the complex MMF zone triggered the exhumation of small, fault-bound crustal blocks within the fault zone as documented by middle Miocene apatite fission track ages. Overall, ages are similar on both sides of the fault suggesting that lateral extrusion along the MMF was not associated with significant differential vertical motions. Local Pliocene rock cooling and exhumation was probably related to the buttressing effect of the underthrust Bohemian basement spur. Whereas large-scale, post-extrusion surface uplift of the extruding crustal wedges, such as the "Styrian block," must have been related to long-wavelength deformation processes affecting the easternmost Alps.
\end{abstract}

\section{Introduction}

The Alpine orogenic belt in central Europe shows remarkable along-strike differences in the distribution of the major tectonic units, its architecture and its tectonic evolution (e.g., Handy et al., 2010; Rosenberg et al., 2015; Schmid et al., 2004). What makes the eastern part of the Alps unique is that it has been strongly influenced by processes operating at a high angle to the overall north-south orientated plate convergence in this region, which started in the Oligocene. These processes include subduction roll-back along the Carpathian arc and associated opening of the Pannonian back-arc basin (e.g., Horváth et al., 2006; and references therein). Both were key for facilitating Miocene orogen-parallel material transport in the Eastern Alps, often referred to as "lateral extrusion" (e.g., Ratschbacher et al., 1991; Ratschbacher et al., 1991). This process describes the combined effect of gravitational collapse of thickened crust (the region of the Tauern window) and lateral escape, driven by the indentation of the Adriatic plate (Frisch et al., 2000; Ratschbacher, Frisch, et al., 1991; Ratschbacher, Merle, et al., 1991; Wölfler et al., 2011). Major, crustal-scale sinistral and dextral strike-slip faults together with normal sense detachment faults were the main agents accommodating orogen-parallel extension and extrusion in the Eastern Alps (Figure 1). Fault formation resulted in fragmentation of the brittle crust into fault-bound blocks that moved in an easterly direction, away from the rising and exhuming Tauern window in the west (Bartosch et al., 2017; Ratschbacher, Frisch, et al., 1991). Ratschbacher, Frisch, et al. (1991) emphasized a change of the deformation regime from compressive/transpressive at the Tauern window to transtensive/extensive when approaching the Pannonian basin. As such extrusion of the easternmost fault block, "wedge 1" sensu 


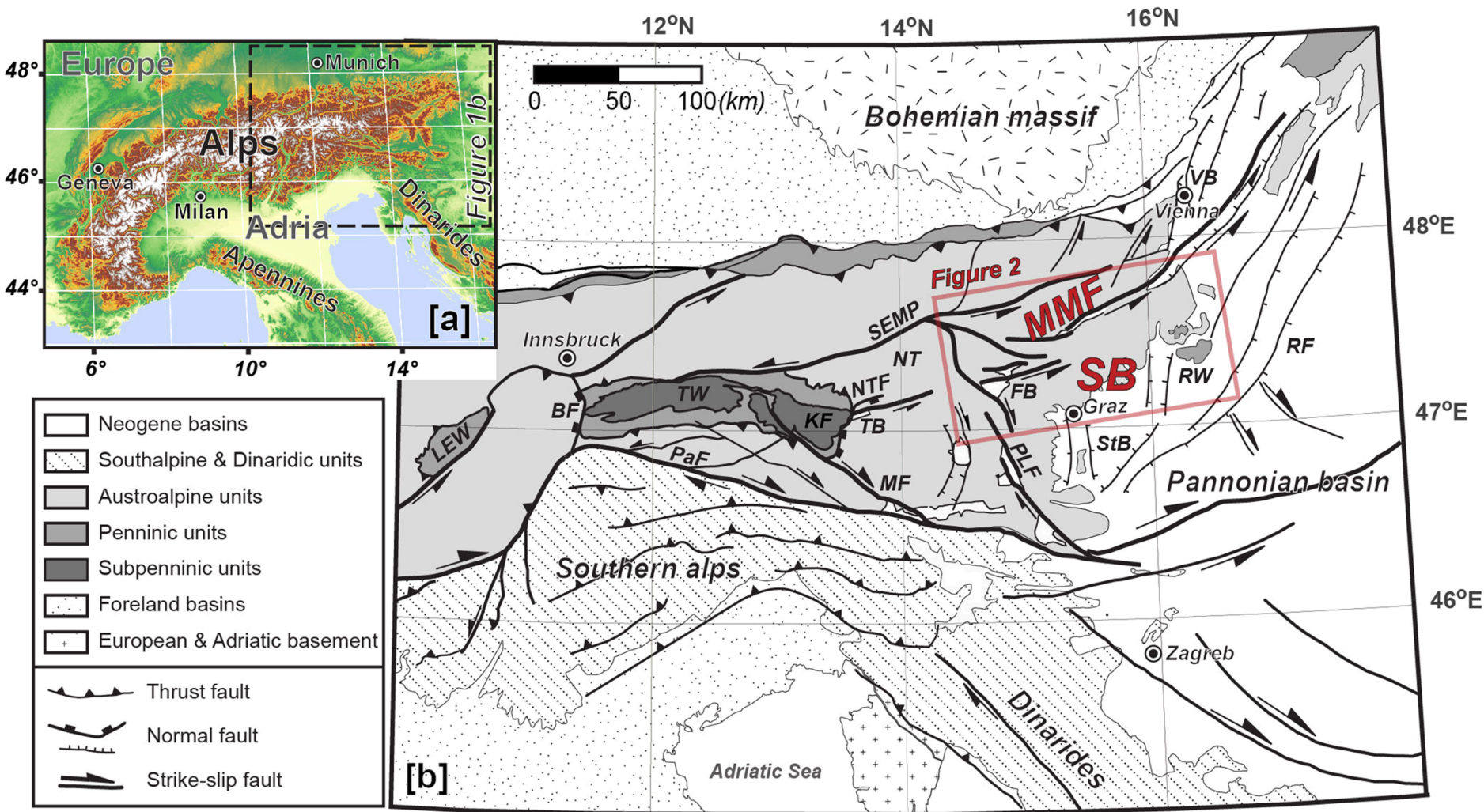

Figure 1. (a) Digital elevation model of the Alps and surrounding regions. The dashed box outlines the area of the tectonic map in (b). (b) Simplified tectonic map of the Eastern Alps and its surroundings illustrating the main Paleogene and Neogene structural features. The map is modified after Willingshofer and Cloetingh (2003) and Froitzheim et al. (2008). The red box outlines the area presented in Figures 2 and 5. Styrian block (SB), Mur-Mürz fault (MMF), Periadriatic fault (PaF), Pöls-Lavanttal fault (PLF), Salzach-Ennstal-Mariazell-Puchberg fault (SEMP), Mur-Mürz fault (MMF), Brenner normal fault (BF), Katschberg normal fault (KF), Mölltal fault (MF), Raaba fault (RF), Tauern window (TW), Lower Engadine window (LEW), Niedere Tauern (NT), Niedere Tauern fault (NTF), Rechnitz window (RW), Tamsweg basin (TB), Fohnsdorf basin (FB), Styrian basin (StB), and Vienna basin (VB).

Ratschbacher, Frisch, et al. (1991) or the "Styrian block" sensu Wagner et al. (2011) is thought to have occurred under strike-slip conditions, with negligeble vertical components of displacement.

In this study, we test this hypothesis through the analysis of new field and low-temperature thermochronology data (zircon and apatite fission track data) that were collected along the northern boundary of the Styrian block, the Mur-Mürz fault (MMF). In particular, we characterize deformation along the MMF prior to, during, and after the Miocene extrusion of the Styrian block and assess its significance for the cooling and exhumation history of the study area. Through this approach we quantify and discuss vertical motions associated with the lateral extrusion of fault-bound blocks and evaluate the role of the MMF during the surface uplift of the eastern part of the Eastern Alps.

\section{Geological Framework}

The tectonic units that compose the Eastern Alps include (from bottom to the top) continental crust derived from the distal European passive margin (the Helvetic and Sub-Penninic units), deep water sediments and ophiolites from the Alpine Tethys ocean (Penninic units), and a nappe stack consisting of continental basement and cover sequences originating from the Adriatic plate (Austroalpine unit). Slices from the Neotethys ocean (Meliata unit) appear within the latter unit (Neubauer et al., 2000; Schmid et al., 2004; and references therein).

The Austroalpine units were stacked during complex tectonic processes related to the closure of the Neothetys ocean in Late Jurassic and Cretaceous times (Froitzheim et al., 2008). Medium to high-grade peak metamorphic conditions were reached at ca. 100-90 Ma (e.g., Hoinkes et al., 1999; Thöni, 2006) followed by 
Late Cretaceous (starting at ca. $80 \mathrm{Ma}$ ) cooling during extension and erosion of the orogenic wedge within an overall N-S convergent and E-W extending regime (Neubauer et al., 1995; Willingshofer et al., 1999).

The Cretaceous orogeny was followed by subduction of the Alpine Tethys ocean and subsequent collision of the European and Adriatic plates (e.g., Handy et al., 2010; Neubauer et al., 2000) during the Late Eocene to Oligocene, as indicated by the onset of sedimentation in the Alpine foreland basin (Kuhlemann \& Kempf, 2002). This collision led to crustal thickening and Oligocene Barrovian metamorphism of the underthrust European margin (Favaro et al., 2015; Schmid et al., 2013). Tectonic units of the lower plate and the ocean are now exposed along the northern margin of the Eastern Alps and within tectonic windows in the core of the orogen; that is, the Lower Engadine, Tauern, and Rechnitz windows (Figure 1). These windows formed during orogen parallel extrusion, which was linked to the indentation of the Adriatic plate, starting no later than ca. $28 \mathrm{Ma}$, and subsequent eastward lateral extrusion of the Eastern Alps, commencing at ca. $23 \mathrm{Ma}$ (Favaro et al., 2015; Ratschbacher, Frisch, et al., 1991). This process was facilitated by back-arc extension that began at $19 \mathrm{Ma}$ at the latest (Horváth et al., 2006), or as early as 25-28 Ma (Matenco \& Radivojević, 2012).

Major strike-slip faults associated with extruding crustal blocks, east of the Tauern window, include the sinistral Salzach-Ennstal-Mariazell-Puchberg fault (SEMP), the sinistral Mur-Mürz fault (MMF), the dextral Periadriatic fault (PaF), and the dextral Pöls-Lavanttal fault (PLF) as shown in Figure 1b. The escaping blocks are regarded as semirigid where deformation mainly concentrated along the bounding faults that accommodated dominantly horizontal (eastward) motion (Linzer et al., 2002). The major crustal blocks are referred to as the "Gurktal block," the "Saualpe block," and the "Styrian block."

The Styrian block is the easternmost extruding wedge and is confined to the north by the NE-SW striking MMF, a sinistral en-echelon strike-slip fault system, and to the west by the NNW-SSE striking PLF with a dextral offset (Figures $1 \mathrm{~b}$ and 2). The eastern boundary is less well defined or considered as open (Wagner et al., 2011) but might coincide with the Raaba fault, which accommodated sinistral strike-slip deformation with a normal slip component. The amount of sinistral displacement along the $\sim 250 \mathrm{~km}$ long MMF is debated and estimates vary between $~ 33$ (Linzer et al., 2002) and $20 \mathrm{~km}$ (Wölfler et al., 2008). Dextral offset along the conjugate PLF amounts to 15-20 km (Kurz et al., 2011; Linzer et al., 2002).

Several Miocene pull-apart basins developed along the MMF. The Fohnsdorf basin was the largest and formed at the intersection with the PLF and is connected to the Seckau basin further to the east (Figure 2). Both basins initially formed separately between overstepping en-echelon strike-slip fault segments during E-W directed extension (Strauss et al., 2001). The Leoben and Mürtztal basins formed to the east of the Fohnsdorf and Seckau basins, which is now the area of St. Marein and Mürzzuschlag (Sachsenhofer et al., 2010; Schuster et al., 2016). The eastern extent of the MMF marks the transition to the Vienna basin, a polyphase basin that formed between 16 and 9 Ma (e.g., Decker, 1996; Fodor, 1995; Lee \& Wagreich, 2017). Formation of the Vienna basin coincided with the main phase (18-15 Ma) of subsidence and sedimentation in the pull-apart basins and the Lavantal basin, which evolved along the PLF (e.g., Kurz et al., 2011; Pischinger et al., 2008; Sachsenhofer et al., 2000).

Lateral extrusion continued into the Late Miocene but stagnated when incipient E-W shortening occurred (Peresson \& Decker, 1997a). This shortening direction has been reported for the Northern Calcareous Alps (Fodor, 1995; Peresson \& Decker, 1997a; Peresson \& Decker, 1997b), the area close to the Periadriatic fault (Fodor et al., 1998) and in the study area along the northern continuation of the AngerPiregg fault (Schuster et al., 2016). Furthermore, E-W shortening triggered inversion of the pull-apart basins (e.g., Decker, 1996; Pischinger et al., 2008; Reischenbacher \& Sachsenhofer, 2013; Sachsenhofer et al., 2000; Wagner et al., 2010).

Also, the interior of the Styrian block was affected by faulting and extension. While the extensional Styrian basin formed in the center of the block (Ebner \& Sachsenhofer, 1995), the northern (Gleinalpe and Fischbacher Alpen) and western (Koralpe) areas of the block experienced surface uplift of several hundreds of meters. These areas contain partly preserved paleosurfaces that dip toward the basin (Schuster et al., 2016; Wagner et al., 2011). Farther to the east, extension caused the exhumation of Penninic rocks within the Rechnitz window (Cao et al., 2013; Dunkl \& Demény, 1997). This phase of vertical motions coincided with early Miocene activity of the MMF and PLF. A second phase of surface uplift of at least $400 \mathrm{~m}$ began in the Pleistocene and continued until recent times (Legrain et al., 2014; Wagner et al., 2011) and coincided with the inversion of the Styrian basin (Ebner \& Sachsenhofer, 1995). 


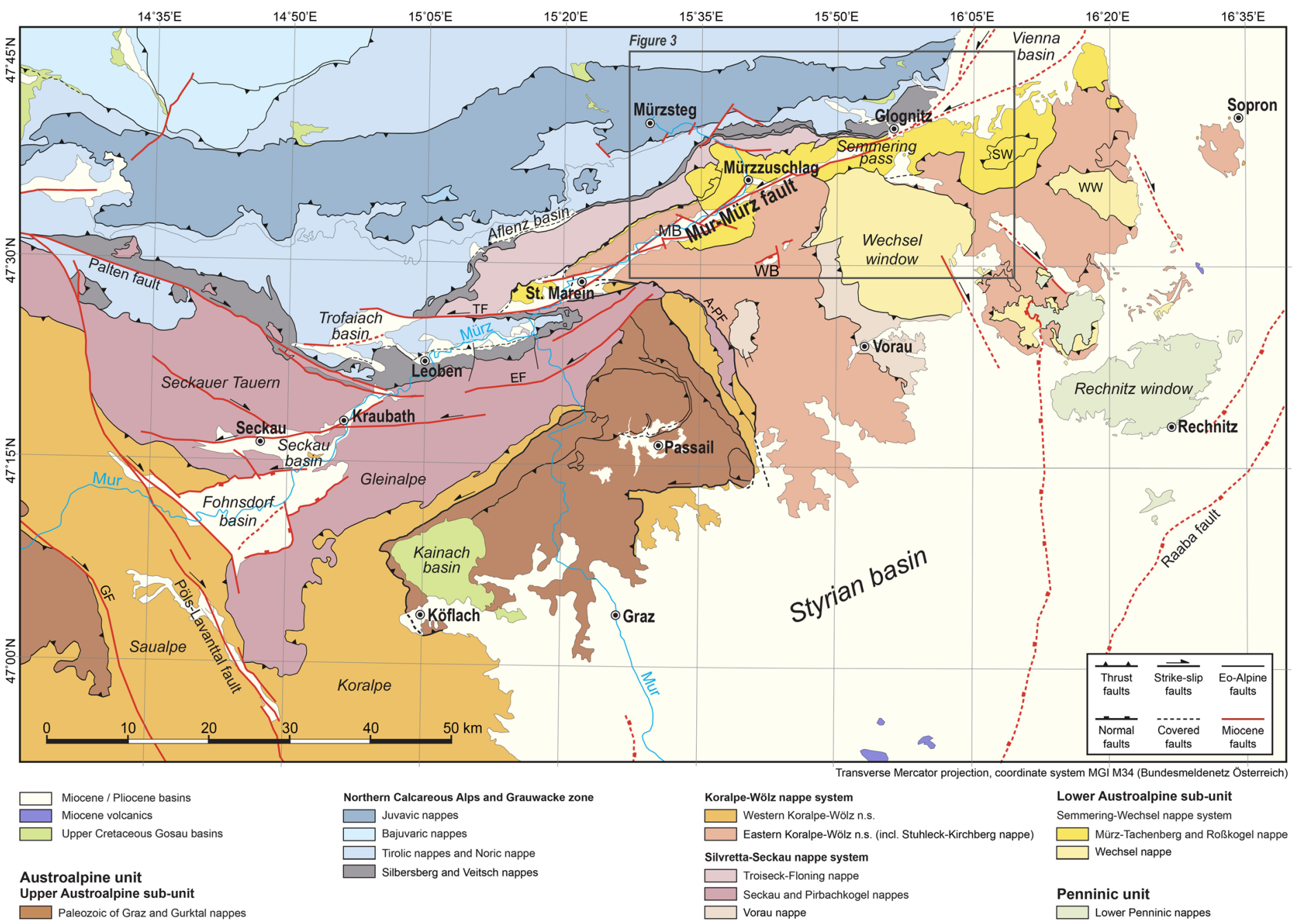

Figure 2. Tectonic map of the eastern part of the Eastern Alps featuring the MMF, the northern segment of the PLF, and other regional structures (compiled and modified from Flügel and Neubauer, 1984; Froitzheim et al., 2008; Neubauer et al., 1995; Schuster et al., 2001; Willingshofer and Neubauer, 2002). The thick black lines are the Late Cretaceous-Paleogene structures, which are dominantly thrust faults, and the red lines trace the Miocene strike-slip and normal faults. The black box illustrates the outline of the geological map used in Figure 4. Mürztal basin (MB), Waldheimat basin (WB), Trofaiach fault (TF), Eiwegg fault (EF), AngerPiregg fault (A-PF), Scheiblingkirchen window (SW), and Wiesmath window (WW).

\section{Kinematics Along the Mur-Mürz Fault}

\subsection{Approach and Methodology Used for Stress Regime Analysis}

Kinematic and fault slip analysis was targeted along the north-eastern segment of the MMF, including the transition from the MMF to the Vienna basin (Figure 2). The studied segment of the fault and its surroundings are characterized by a topographic high, the Semmering pass, while the main extent of the fault is marked by an incised ENE-WSW striking valley. Most of the data stem from the flanks of the valley and are complemented by data from dominantly NNW-SSE striking side valleys. A total of 131 outcrops were studied and used to reconstruct the sequence of brittle deformation phases along the MMF.

Collected structural data are fault planes and their associated kinematic indicators (Angelier, 1994; Petit, 1987), including Riedel shears, tension gashes, and striations such as slickensides, steps, and stylolites. The measurements are accompanied by the description of qualitative observations, such as time relations between the different sets of brittle deformation structures, for example, cross-cutting fault planes and Riedel shears, or reactivated fault planes emphasized by overprinting relations of striations. Other qualitative observations include the rock type, fracture dimensions, associated crystallization of calcite, and a confidence level for the sense of shear. 
Table 1

Results of the Stress Tensor Analysis Providing the Mean Stress Orientation for Each Deformation Phase

\begin{tabular}{|c|c|c|c|c|c|c|c|c|c|}
\hline \multirow[b]{2}{*}{ Phase } & \multirow[b]{2}{*}{$\mathrm{N}$} & \multicolumn{2}{|c|}{$\sigma 1$} & \multicolumn{2}{|c|}{$\sigma 2$} & \multicolumn{2}{|c|}{$\sigma 3$} & \multirow[b]{2}{*}{$\mathrm{R}$} & \multirow[b]{2}{*}{$\mathrm{R}^{\prime}$} \\
\hline & & $\operatorname{dip}$ & d.d. & dip & d.d. & dip & d.d. & & \\
\hline D1 & 249 & 22 & 149 & 68 & 330 & 00 & 240 & 0.65 & SF \\
\hline D2 & 172 & 31 & 050 & 56 & 260 & 14 & 148 & 0.60 & NS \\
\hline D3 & 659 & 02 & 191 & 87 & 042 & 01 & 281 & 0.45 & SF \\
\hline D4 & 279 & 29 & 270 & 61 & 089 & 01 & 180 & 0.68 & SF \\
\hline
\end{tabular}

Note. Number of measurements included $(N)$, principle finite stress axes $(\sigma 1, \sigma 2$, and $\sigma 3)$, dip direction (d.d.), stress ratio $(\mathrm{R})$, tectonic stress regime ( $\left.\mathrm{R}^{\prime}\right)$ with the categories normal faulting (NF), transtensive faulting (NS), strike-slip faulting (SF), transpressive faulting (TS), and thrust faulting (TF). The data are graphically presented in Figure 3.

To analyze the kinematic data, the Win-Tensor software (Delvaux \& Sperner, 2003) was used. The program assumes that slip on a plane occurs in the direction of the maximum shear stress and results in the calculation of the reduced tectonic stress tensor, including the principal stresses, which are in decreasing order $\sigma_{1}$, $\sigma_{2}$, and $\sigma_{3}$, respectively. The pertinent stress regime for each data set is characterized by the stress regime index $\left(\mathrm{R}^{\prime}\right)$, which provides a numerically continuous progression from 0 to 3 , where 0 represents radial extension and 3 radial compression (Delvaux et al., 1997). $\mathrm{R}^{\prime}$ is based on the stress ratio (R), defined as $\left(\sigma_{2}-\sigma_{3}\right) /\left(\sigma_{1}-\sigma_{3}\right)$ (e.g., Angelier, 1989) such that $\mathrm{R}^{\prime}$ equals $\mathrm{R}$ for extensional stress regimes, equals $2-\mathrm{R}$ for strike-slip regimes, and equals $2+\mathrm{R}$ for compressional regimes, respectively (Delvaux et al., 1997). Most outcrops contained sufficient data to perform a multiphase stress tensor analysis to derive a series of deformation phases, taking into account the observed time relations between the different structures. The approach used to separate the data sets into multiple phases is done in a similar fashion as described in Kipata et al. (2013). This statistical approach for the analysis of fault slip data was used because of the lack of unique traceable markers on either side of the fault, which would allow for direct reconstruction of the slip vector from kinematic field data. In fact, the MMF cuts at a small angle through the Cretaceous nappe stack and thus stays over long distances within the same thrust sheet, which renders the correlation of tracers across the fault impossible. However, we are confident that the results are geologically meaningful as a good correlation can be demonstrated with geological observations from the sedimentary basins along the fault (see section 4).

\subsection{Field Kinematics Along the Mur-Mürz Fault}

The kinematic analysis along the MMF has resulted in the differentiation of four main deformation phases, based on time relations observed in 21 outcrops. The description of the stress regimes corresponding to the four deformation phases are listed in Table 1 and are graphically presented in Figure 3. Furthermore, the results of the fault slip analysis are listed per outcrop in van Gelder et al. (2020).

\subsubsection{D1: NNW-SSE Shortening Within a Strike-Slip Dominated Regime}

The oldest phase of deformation (D1) is characterized by N-S striking sinistral strike-slip faults accompanied by conjugate WNW-ESE striking dextral strike-slip faults (Figure 3a). Fault planes are steeply dipping and contain dominantly shallow plunging striations (see the rose diagrams in the inset in Figure 3a) attesting of strike-slip faulting. Steep planes, which deviate from the mean N-S strike, for example, a NNE-SSW strike, have a strong oblique-normal slip component (e.g., stereoplot of outcrop 92 in Figure 3a). Furthermore, normal faulting also occurs within the D1 phase along NW-SE striking fault planes with SW and NE plunging striations, for example, outcrops 48 and 52 (Figure 3a).

Overall a total of 32 locations with a sum of 249 fault planes are ascribed to the D1 phase reflecting a strike-slip event with a mean $\mathrm{R}^{\prime}$ of 1.23 (map inset in Figure 3a). The strike-slip regime is characterized by a NNW-SSE direction of contraction $(\sigma 1=149 / 22)$ and NE-SW extension $(\sigma 3=240 / 00)$. The individual stations primarily reflect these strike-slip regimes except for the locations with dominant normal faulting which results in an extensional stress regime (Figure 3a). However, both regimes are characterized by the same principal direction of extension. These D1 stress regimes are concentrated in two clusters along the MMF: A first cluster is located at and around the Semmering pass, and a second cluster is located to the SW of Mürzzuschlag (Figure 3a). 
[a]

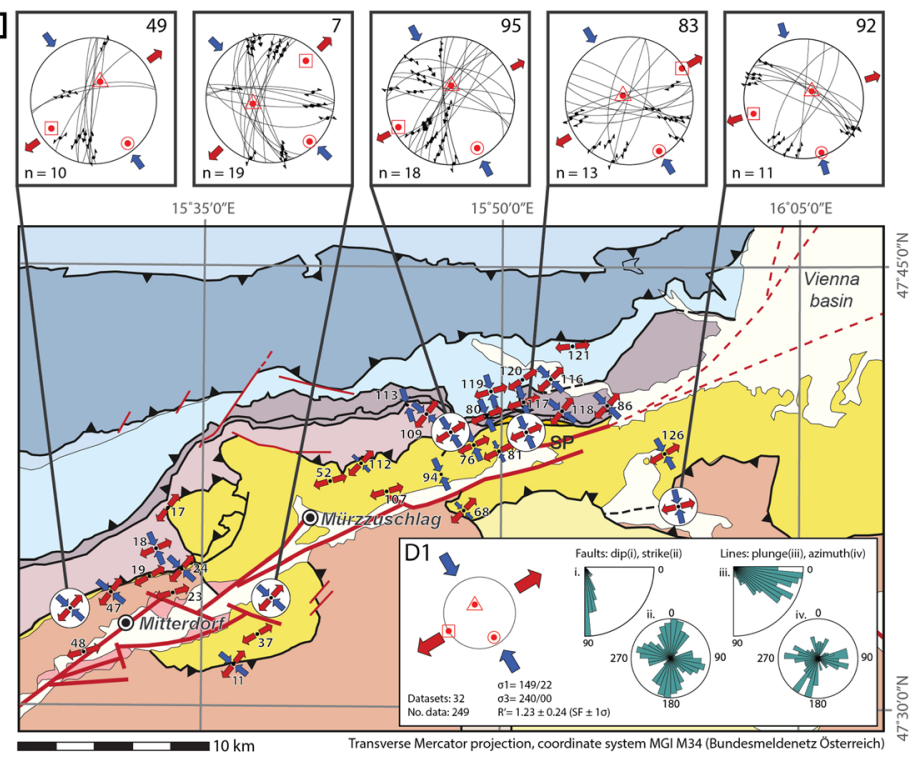

[c]



[b]

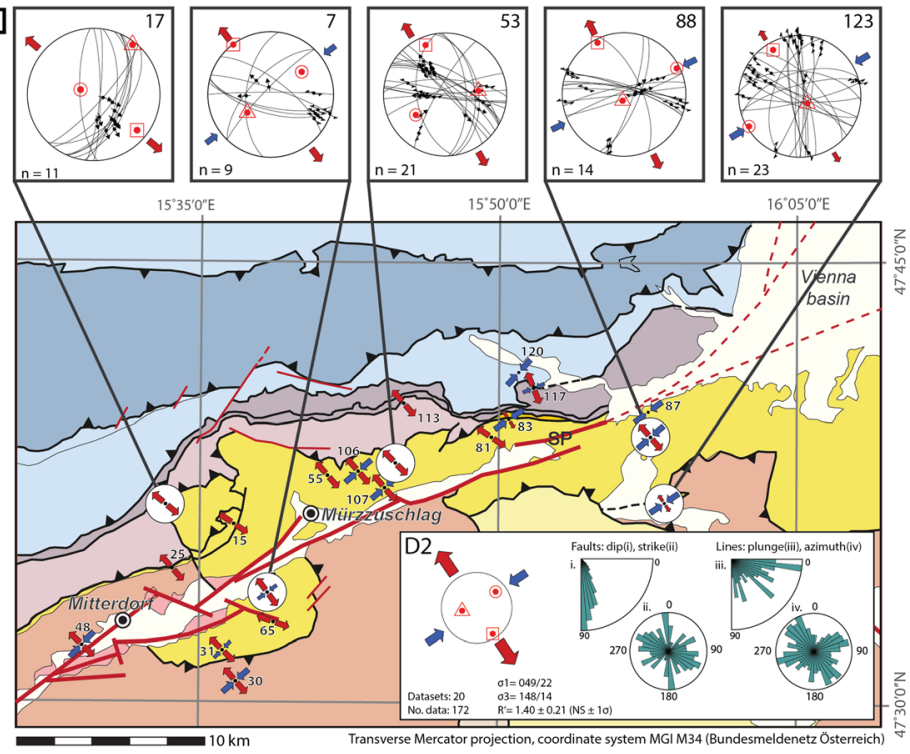

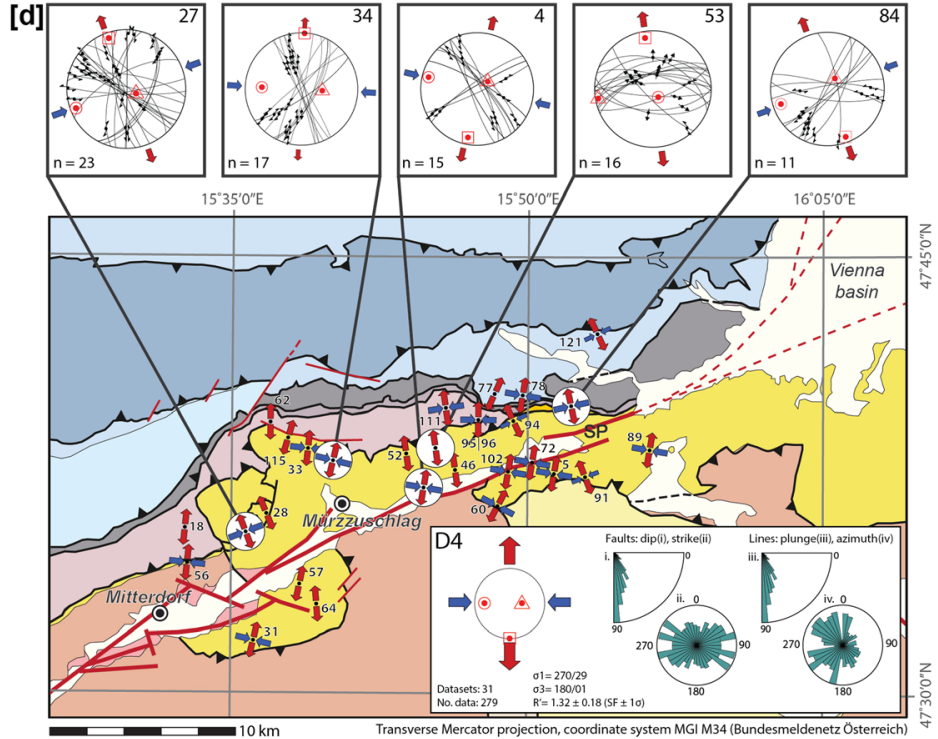

Figure 3. Summary of fault slip analysis of D1 (a), D2 (b), D3 (c), and D4 (d) deformation phases. All figures display the horizontal stress axes per outcrop on the tectonic map (red and blue arrows) together with a selection of stereoplots of key outcrop locations showing the measured fault planes, the fault kinematics, the associated stress regime, and the orientation of the $\sigma 1$ ( $\mathrm{Sh}_{\max }$, red circles), $\sigma 2$ (red triangles), and $\sigma 3$ ( $\mathrm{Sh}_{\min }$, red squares). The length of the red and blue arrows is proportional to the magnitude of the horizontal deviatoric stress with respect to the isotropic stress (Delvaux et al., 1997). The insets in the maps feature the stress tensor specifications for the pertinent deformation phase based on the compilation of fault planes and associated kinematics. The number of data sets and the amount of fault planes included (No. data) are listed below the stress tensor, along with the mean values for the $\sigma 1\left(\mathrm{Sh}_{\max }\right)$ and $\sigma 3\left(\mathrm{Sh}_{\min }\right)$ and the obtained stress regime index $\left(\mathrm{R}^{\prime}\right)$ and associated deviation. The orientation of the $\sigma 1$ ( $\mathrm{Sh}_{\mathrm{max}}$, red circle), $\sigma 2$ (red triangle), and $\sigma 3$ ( $\mathrm{Sh}_{\mathrm{min}}$, red square) is also displayed on the stereoplot. The presented series of rose diagrams show (i) dip of the fault planes, (ii) strike of the fault planes, (iii) plunge of the striations, and (iv) trend of striations. See Figure 2 for legend of tectonic units. The corresponding results of the calculations is listed in van Gelder et al. (2020). Semmering pass (SP).

\subsubsection{D2: Transtension With NE-SW Shortening and NW-SE Extension Direction}

The second deformation event (D2) with mainly obliquely slipping strike-slip faults is less strongly developed compared to D1. Only 20 data sets could be ascribed to this event with a total of 172 fault planes and their associated kinematic indicators (Figure 3b). The stress tensor that is obtained when combining the data sets yields NE-SW directed contraction $(\sigma 1=049 / 22)$ and NW-SE directed extension $(\sigma 3=148 / 14)$ with a mean $\mathrm{R}^{\prime}$ of 1.4 (map inset in Figure $3 \mathrm{~b}$ ). The combined data produces a stress regime, which indicates that $\mathrm{D} 2$ is transtensive. 
The D2 extensional structures include NW and SE dipping oblique-normal faults with dip angles between $50^{\circ}$ and $70^{\circ}$ (see, e.g., outcrop 17, Figure 3b). Furthermore, strike-slip faulting occurred along N-S striking dextral faults (peak in the rose diagram in map inset in Figure 3b), as well as sinistral WNW-ESE striking faults. The scatter in the rose diagram representing the orientation of fault striae shows that the strike-slip and normal faults have a strong oblique component of slip.

\subsubsection{D3: Strike-Slip Faulting During NNE-SSW Shortening}

A total of 48 locations representing 659 fault planes and their kinematic indicators are part of a third deformation phase (D3), comprising the most profound deformation event along the MMF (Figure 3c). D3 structures reflect a strike-slip deformation regime (see map inset in Figure 3c) with NNE-SSW directed contraction $(\sigma 1=191 / 02)$ and WNW-ESE directed extension $(\sigma 3=281 / 01)$ and an average $\mathrm{R}^{\prime}$ of 1.55 .

The structures associated with D3 are dominantly NW-SE striking dextral faults and conjugate ENE-WSW striking sinistral faults, for example, see the stereoplots of outcrop 62 or 84 in Figure 3c. The dominance of these fault plane orientations is clearly reflected in the rose diagrams (map inset in Figure 3c). The foremost sub-horizontal transport direction reflected in the rose diagram of the striations is in accordance with strike-slip kinematics. Furthermore, the azimuth of the striations has a slightly larger scatter as the strike of the faults, suggesting that some faults are also associated with oblique slip displacements.

The D3 phase is observed along the entire studied section of the MMF. The map in Figure 3c shows that most outcrops are associated with a D3 strike-slip regime. However, in some outcrops the deformation event is locally expressed by a contractional or extensional regimes, for example, outcrops 32 and 42 (Figure 3c). Moreover, the direction of extension or contraction corresponds to the above described $\sigma 3$ and $\sigma 1$, respectively.

\subsubsection{D4: E-W Directed Shortening and Reactivation of D3 Faults}

The last phase of deformation (D4) is distinguished in 31 locations along the studied section of the MMF and includes 279 measurements of fault planes and associated kinematic indicators (Figure 3d). D4 is expressed by a stress tensor with E-W directed contraction $(\sigma 1=270 / 29)$ and $\mathrm{N}-\mathrm{S}$ directed extension $(\sigma 3=180 / 01)$ encompassing an overall strike-slip stress regime with a mean stress ratio of 0.68 . Faults that were active during this phase are often reactivated fault planes. Most D4 kinematics are observed near the eastern extend of the MMF (Figure 3d). Characteristic faults for this phase include north and south dipping normal faults (e.g., stereoplot of outcrop 53 in Figure 3d), NE-SW striking dextral faults, and NW-SE striking sinistral faults (e.g., outcrop 4, Figure 3d). The strike of the strike-slip faults is similar to D3 faults, but the sense of displacement along the faults is opposite, suggesting reactivation of the structures. The same applies for the other D4 structures, for example, inverted normal faults. From the rose diagrams, as seen in the map inset in Figure 3 $\mathrm{d}$, it emerges that steep faults are dominant, whereas the strike of the structures shows a more scattered distribution compared to previous deformation phases. This is in line with our observation that many previously formed structures were reactivated during the D4 event.

\section{Interpretation of the Structural Data}

The structural data presented in section 3 are interpreted within the frame of eastward lateral extrusion of the eastern Eastern Alps. Our interpretation is based on a comparison with deformation histories deduced from extrusion related sedimentary basins, which enables to embed our results in a stratigraphically controlled time frame (Figure 4).

NNW-SSE shortening within an overall transpressional stress regime is characteristic for D1. This shortening direction is in our view not compatible with the activation of the overall 060 striking MMF as a sinistral strike-slip structure unless the fault would have had a NNE-SSW strike at that time, which is not known. Faults along the MMF that could have been activated during this phase are minor N-S striking sinistral faults near Kraubath (Figures 2 and 4). Although similar early Miocene shortening directions were inferred along the conjugate Pöls-Lavanttal strike-slip fault (Pischinger et al., 2008), we propose that our D1 kinematics are early Miocene or older but are not directly linked to lateral extrusion of the Styrian block for the reason given above. However, our D1 shortening direction is consistent with those related to the pre-extrusion piggy-back basin phase of the Vienna basin during the early Miocene (Ottnangian and early Karpatian) and out-ofsequence thrusting within the Northern Calcareous Alps (see Figure 4, Beidinger \& Decker, 2014; Decker et al., 2005; Fodor, 1995; Hölzel et al., 2010). 


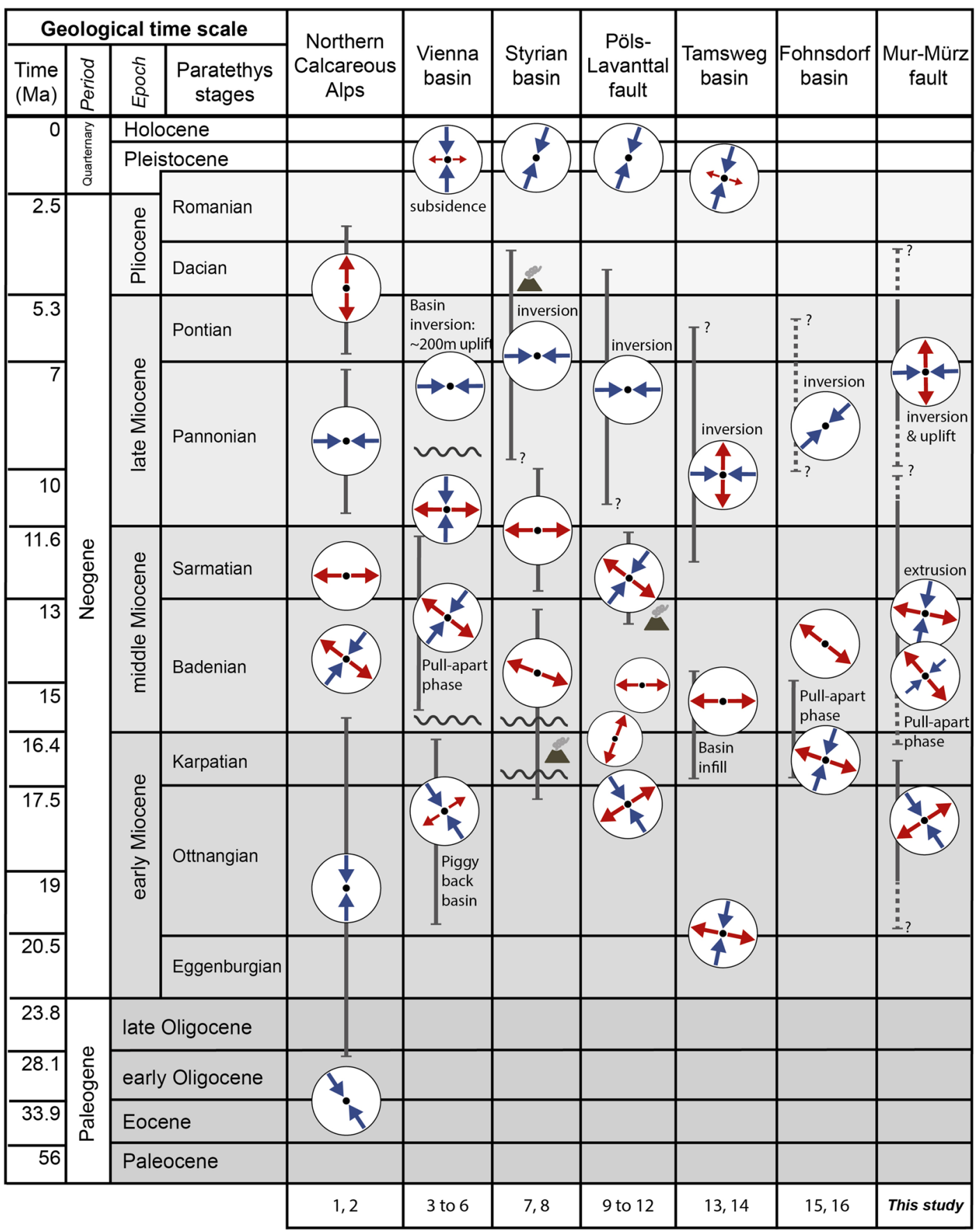

Figure 4. Comparison of the presented deformation phases along the MMF to published deformation histories determined in extrusion related sedimentary basins of the Eastern Alps and other performed fault slip analyses in the eastern Eastern Alps. (1) Peresson and Decker (1997a), (2) Decker et al. (1993), (3) Beidinger and Decker (2011), (4) Hölzel et al. (2010), Fodor (1995), (6) Decker (1996), (7) Ebner and Sachsenhofer (1995), (8) Hohenegger et al. (2009), (9) Ratschbacher, Frisch, et al. (1991), (10) Reischenbacher and Sachsenhofer (2013), (11) Kurz et al. (2011), (12) Pischinger et al. (2008), (13) Zeilinger et al. (1999), (14) Reinecker and Lenhardt (1999), (15) Strauss et al. (2001), and (16) Sachsenhofer et al. (2010).

Fault slip analysis suggests that the shortening direction changed from NNW-SSE (D1) to NE-SW (D2) to NNE-SSW (D3). Although field relations allow to discriminate among D2 and D3 related structures, the exact timing of the two events remains uncertain. The compatibility between shortening direction and fault orientation suggests that D2 and D3 are related to significant sinistral movement of the MMF and associated conjugate dextral faults including the Pöls-Lavanttal fault or the Palten fault (Figure 2). The roughly NE-SW 
contraction associated with D2 and D3 kinematics also triggered reactivation of earlier formed structures, such as the E-W striking normal fault along the northern rim of the Waldheimat and the Leoben basins, which is interpreted to have occurred during the middle Miocene (Gruber \& Sachsenhofer, 2001; Neubauer \& Unzog, 2003; Sachsenhofer et al., 2010; Strauss et al., 2001).

The D2 and D3 phases also lead to the formation of pull-apart basins, including the Lavanttal, Seckau, or Vienna basins (Figures 2 and 4; Gruber \& Sachsenhofer, 2001; Fodor, 1995; Reischenbacher \& Sachsenhofer, 2013; Strauss et al., 2001) and coincided with the formation of the Styrian basin (Ebner \& Sachsenhofer, 1995). As such these phases are interpreted to be related to the middle Miocene main phase of lateral extrusion in this part of the Eastern Alps (Frisch et al., 2000; Ratschbacher, Frisch, et al., 1991; Wölfler et al., 2011). For all basins, rapid subsidence was associated with either a strike-slip or an extensional regime, where both stress regimes are characterized by a similar D2 NE-SW directed $\sigma 1$ (Figure 4). Subsequent D3 records deformation related to an NNE-SSW directed $\sigma 1$ and strike-slip deformation conditions, in agreement with lateral material transport during extrusion. Furthermore, structures in the eastern part of the Northern Calcareous Alps (Peresson \& Decker, 1997b) document similar shortening directions and deformation regimes during this time span (Figure 4).

According to kinematic and stratigraphic data from basins along the MMF, the strike-slip kinematics, representative for our D1, D2, and D3 kinematics, cease during the Pannonian when inversion and uplift of the basins occurred as a result of E-W contraction (see Figure 4; e.g., Pischinger et al., 2008; Strauss et al., 2001; Zeilinger et al., 1999). The presented D4 kinematics along the MMF is characterized by reactivation of older structures in response to E-W contraction and associated N-S extension, together defining a strike-slip regime (Figure 3d). We therefore correlate the D4 stress regime with inversion of the basins during the Late Miocene to possibly early Pliocene. This phase has reactivated segments of the sinistral MMF with a dextral sense of shear and N-S striking normal faults as reverse faults.

\section{Zircon and Apatite Fission Track Analysis}

The field kinematic analysis presented above suggests that deformation prior to, during, and after the activity of the MMF pertains to predominantly lateral material transport under brittle conditions. We test this idea through zircon fission track (ZFT) and apatite fission track (AFT) thermochronology across the MMF, which allows for interpreting cooling ages in terms of vertical motions.

\subsection{Sampling Strategy and Analytical Procedures}

Samples were taken along three sampling lines crossing the MMF at a high angle (Figure 5 and Table 2). Preferentially sampled lithologies were (ortho-)gneisses and mica-schists from upper greenschist to amphibolite facies metamorphic rocks of the Upper and Lower Austroalpine nappes. The three sampling lines, with a total of 29 sampling sites (Figure 5 and Table 2), are located near the cities of Kraubath (KR-sampling line), Sankt Marein (SM-sampling line), and west of the Semmering pass (S-sampling line) and roughly represent a western, middle, and eastern transect across the MMF, respectively.

Using a standard mineral separation procedure (e.g., Merten, 2011), performed at the VU University Amsterdam (The Netherlands), apatites and zircons were extracted from 3 to $4 \mathrm{~kg}$ of collected rock per sample. After mineral separation zircons and apatites were prepared for irradiation which includes mounting, grinding, polishing, and etching of the crystals. The mounts were covered with an external detector (an annealed white mica) which records induced fission during irradiation (e.g., Gleadow, 1981). Furthermore, during irradiation at the FRM II nuclear reactor in Garching (Germany), the neutron flux was monitored with a CN1 dosimeter glass for the zircon mounts and a CN5 dosimeter glass for the apatite mounts.

After irradiation, the density of spontaneous fission tracks in the apatite and zircon grains, and induced fission tracks on the external detectors were measured. Using the Trackkey software, version 4.2 by Dunkl (2002), the single-grain ages for the apatites and zircons were determined as a function of the spontaneous versus induced fission track densities. To calculate the ages, we used the zeta-calibration method by Hurford and Green (1983) with a zeta-factor of $128 \pm 3 \mathrm{acm}^{-2}$ for the CN1 glass (zircons) and $352 \pm 10 \mathrm{acm}^{-2}$ for the CN5 glass (apatites). Additionally, the chi-square $\left(\chi^{2}\right)$ test was used to analyze the homogeneity of the singlegrain ages per sample returning the probability, $P\left(\chi^{2}\right)$, that the single-grain ages are derived from the same 


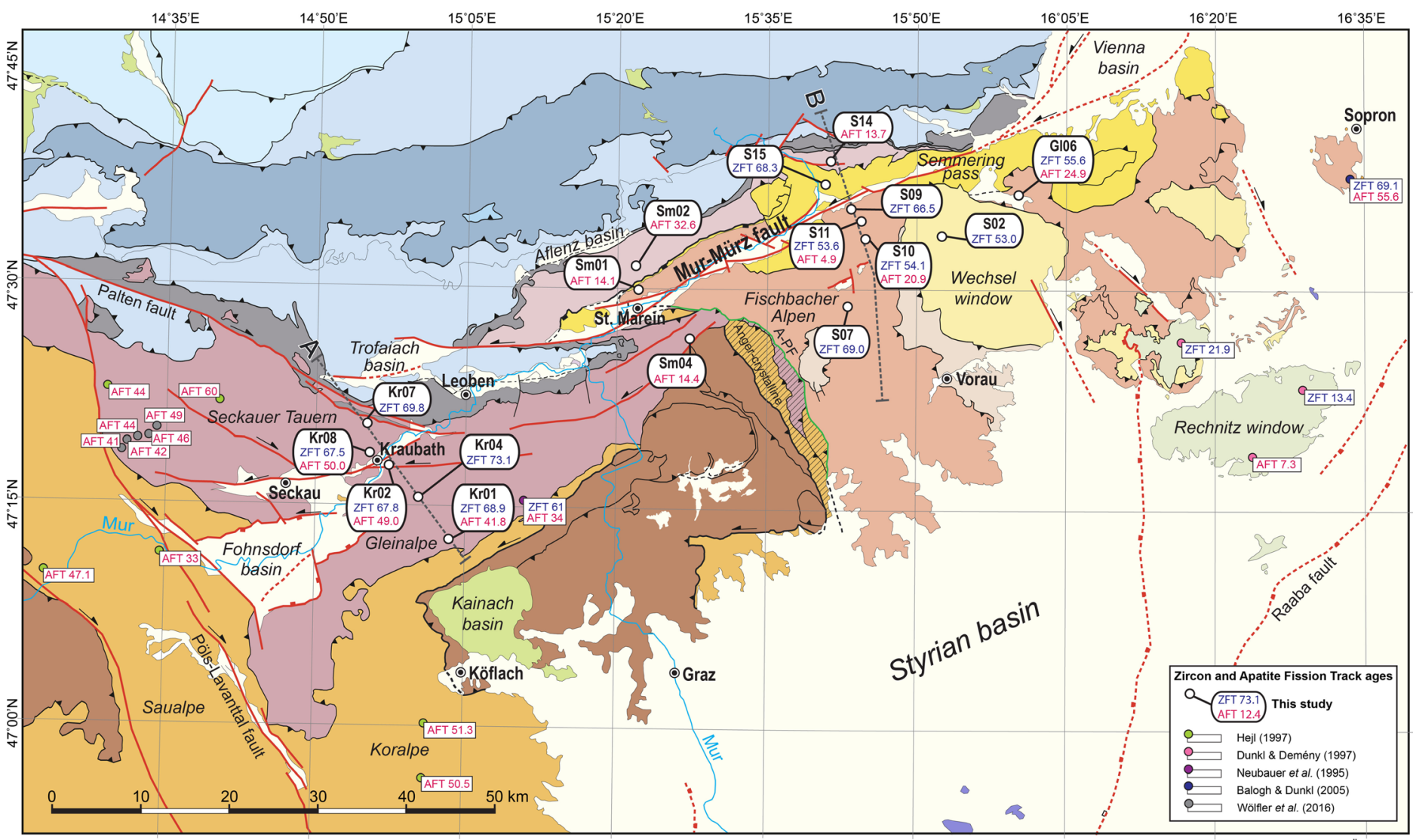

Figure 5. Overview of the areal distribution of new and published ZFT and AFT. Oblique ruling: Latest Cretaceous shear zone after Krenn et al. (2008). Green line: Anger-Piregg fault (A-Pf). For other symbols and legend of tectonic units as well as relevant abbreviations see Figure 2.

population, using $n$ degrees of freedom (where $n$ is the number of crystals minus 1 ). To consider the age population as homogeneous the probability $P\left(\chi^{2}\right)$ needs to be greater than $5 \%$; hence, the sample passes the chi-square test (Barbarand et al., 2003; Bernet, 2009).

Table 2

Lithological, Tectonic, and Spatial Information for the ZFT and AFT Sample Locations

\begin{tabular}{|c|c|c|c|c|c|}
\hline Sample & Lithology & Tectonic unit nappe system/nappe & Coordinates latitude & Coordinates longitude & Elevation (m) \\
\hline $\mathrm{Kr}-01$ & Augengneiss & Silvretta-Seckau/Seckau \& Pirbachkogel & 47.213133 & 15.056967 & 1,616 \\
\hline $\mathrm{Kr}-02$ & Biotite-Paragneiss & Silvretta-Seckau/Seckau \& Pirbachkogel & 47.294967 & 14.997050 & 668 \\
\hline Kr-04 & Biotite-Paragneiss & Silvretta-Seckau/Seckau \& Pirbachkogel & 47.270183 & 14.997050 & 1,050 \\
\hline $\mathrm{Kr}-07$ & Orthogneiss & Silvretta-Seckau/Seckau \& Pirbachkogel & 47.337833 & 14.915833 & 1,475 \\
\hline $\mathrm{Kr}-08$ & Paragneiss & Silvretta-Seckau/Seckau \& Pirbachkogel & 47.309417 & 14.926850 & 692 \\
\hline S-02 & Albitblastengneiss & Semmering-Wechsel/Wechsel & 47.562750 & 15.873917 & 1,181 \\
\hline S-07 & Grobgneiss & Koralpe-Wölz/Stuhleck-Kirchberg & 47.481383 & 15.722950 & 826 \\
\hline S-09 & Grobgneiss & Koralpe-Wölz/Stuhleck-Kirchberg & 47.592583 & 15.723133 & 844 \\
\hline S-10 & Grobgneiss & Koralpe-Wölz/Stuhleck-Kirchberg & 47.559383 & 15.745850 & 1,543 \\
\hline S-11 & Grobgneiss & Koralpe-Wölz/Stuhleck-Kirchberg & 47.578133 & 15.738217 & 1,138 \\
\hline S-14 & Biotite-Gneiss & Silvretta-Seckau/Troiseck-Floning & 47.646033 & 15.689800 & 986 \\
\hline S-15 & Chlorite-Micaschist & Semmering-Wechsel/Mürz-Tachenberg & 47.620617 & 15.677067 & 786 \\
\hline Gl-06 & Grobgneiss & Koralpe-Wölz/Stuhleck-Kirchberg & 47.609750 & 16.005400 & 562 \\
\hline Sm-01 & Grobgneiss & Koralpe-Wölz/Stuhleck-Kirchberg & 47.496283 & 15.367600 & 662 \\
\hline Sm-02 & Augengneiss & Silvretta-Seckau/Troiseck-Floning & 47.523983 & 15.368117 & 917 \\
\hline Sm-04 & Gneiss & Silvretta-Seckau/Seckau \& Pirbachkogel & 47.445633 & 15.454433 & 698 \\
\hline
\end{tabular}

Note. The term "Grobgneiss" refers to a Permian granitic augengneiss, whereas "Albitblastengneiss" represents a paragneiss with albite porphyroblasts. 
Table 3

Zircon Fission Track Analytical Data

\begin{tabular}{|c|c|c|c|c|c|c|c|c|c|c|}
\hline \multirow{2}{*}{$\begin{array}{l}\text { Sample } \\
\text { code }\end{array}$} & \multirow[b]{2}{*}{$\mathrm{N}_{\mathrm{Gr}}$. } & $\mathrm{N}_{\mathrm{s}}$ & $\rho_{s}$ & $\mathrm{~N}_{\mathrm{i}}$ & $\rho_{i}$ & $\mathrm{~N}_{\mathrm{d}}$ & \multirow{2}{*}{$\frac{\rho_{\mathrm{d}}}{\left(\times 10^{6} \mathrm{~cm}^{-2}\right)}$} & \multirow{2}{*}{$\frac{\text { Age }}{(\mathrm{Ma} \pm 1 \sigma)}$} & \multirow{2}{*}{$\frac{P\left(\chi^{2}\right)}{(\%)}$} & \multirow{2}{*}{$\begin{array}{r}\text { Disp. } \\
(\%)\end{array}$} \\
\hline & & & $\left(\times 10^{6} \mathrm{~cm}^{-2}\right)$ & & $\left(\times 10^{6} \mathrm{~cm}^{-2}\right)$ & & & & & \\
\hline $\mathrm{Kr}-01$ & 15 & 1,414 & 48.135 & 656 & 22.331 & 15,508 & 0.50 & $68.7 \pm 3.7$ & 98.28 & 0.00 \\
\hline $\mathrm{Kr}-02$ & 15 & 1,252 & 37.912 & 589 & 17.836 & 15,508 & 0.50 & $67.8 \pm 3.8$ & 99.99 & 0.00 \\
\hline $\mathrm{Kr}-04$ & 15 & 3,572 & 42.379 & 1557 & 18.472 & 15,508 & 0.50 & $73.1 \pm 2.9$ & 55.55 & 0.01 \\
\hline $\mathrm{Kr}-07$ & 11 & 869 & 55.196 & 397 & 25.216 & 15,508 & 0.50 & $69.8 \pm 4.6$ & 97.73 & 0.00 \\
\hline $\mathrm{Kr}-08$ & 14 & 2,010 & 53.824 & 949 & 25.412 & 15,508 & 0.50 & $67.5 \pm 3.1$ & 99.61 & 0.00 \\
\hline S-02 & 15 & 1,654 & 24.613 & 996 & 14.821 & 15,508 & 0.50 & $53.0 \pm 2.5$ & 99.96 & 0.00 \\
\hline S-07 & 13 & 1,336 & 55.007 & 617 & 25.403 & 15,508 & 0.50 & $69.0 \pm 3.8$ & 99.77 & 0.00 \\
\hline S-09 & 12 & 968 & 75.815 & 464 & 36.341 & 15,508 & 0.50 & $66.5 \pm 4.1$ & 100 & 0.00 \\
\hline S-10 & 15 & 1,984 & 64.382 & 1170 & 37.967 & 15,508 & 0.50 & $54.1 \pm 2.4$ & 99.03 & 0.00 \\
\hline S-11 & 15 & 2608 & 108.667 & 1552 & 64.667 & 15,508 & 0.50 & $53.6 \pm 2.2$ & 99.8 & 0.00 \\
\hline S-15 & 13 & 1,015 & 49.638 & 474 & 23.181 & 15,508 & 0.50 & $68.3 \pm 4.2$ & 95.7 & 0.00 \\
\hline Gl-06 & 15 & 2,211 & 67.343 & 1101 & 33.534 & 8,973 & 0.43 & $55.6 \pm 2.5$ & 96.3 & 0.00 \\
\hline
\end{tabular}

Note. The presented ZFT cooling ages are central ages with $1 \sigma$ standard error (Galbraith \& Laslett, 1993). The data are discussed in the text (see also Figures 8 and 10 and Table 2). $\mathrm{N}_{\mathrm{Gr}}=$ number of dated zircon crystals; $\rho_{\mathrm{d}}=$ dosimeter track density; $\mathrm{N}_{\mathrm{d}}=$ number of tracks counted on the dosimeter; $\rho_{\mathrm{d}}\left(\rho_{\mathrm{i}}\right)=\operatorname{spontaneous}$ (induced) track densities; $\mathrm{N}_{\mathrm{S}}\left(\mathrm{N}_{\mathrm{i}}\right)=$ number of spontaneous (induced) tracks counted; $P\left(\chi^{2}\right)=$ probability obtaining chi-square $\left(\chi^{2}\right)$ for $n-1$ degrees of freedom ( $n$ is number of crystals); Disp. $=$ dispersion in single-grain ages.

In addition to analyzing the apatite fission track (AFT) densities used for the age calculation, we measured the length of as many confined tracks as possible. We also measured the diameter of the track opening parallel to the crystallographic c-axis (Dpar) as a proxy for the fission track annealing kinetics (Donelick et al., 1999). The track densities, track lengths, and Dpar were used for modeling the thermal histories using the inverse model of HeFTy software (Ketcham, 2005; Ketcham et al., 2007).

\subsection{Zircon Fission Track Results}

A total of 12 samples contained adequate zircons for age determination and returned ZFT ages range between $73.1 \pm 2.9$ and $53 \pm 2.5 \mathrm{Ma}$. All the measured samples passed the chi-square test (Table 3 and Figure 6). Five of the $12 \mathrm{ZFT}$ ages belong to the KR-sampling line and the remaining seven ZFT ages to the S-sampling line and location Gl-06 (Figures 5 and 8).

Older ZFT ages are documented for samples located along the western transect (KR-sampling line), ranging between $73.1 \pm 2.9$ (sample KR-04) and $67.5 \pm 3.1 \mathrm{Ma}$ (sample KR-08). Somewhat younger ages are found along the eastern transect and range between $69.0 \pm 3.8 \mathrm{Ma}$ in the Fischbach mountains (sample S-07) and $53.0 \pm 2.5 \mathrm{Ma}$ at the Wechsel window (sample S-02).

In contrast to the along-strike trend, the age distributions across the fault do not show any trend, ZFT ages being similar within errors on either side of the MMF. In summary, a first order analysis suggests an age difference along the strike of the MMF with overall younger ZFT ages in the east (Figure 5), independent of their structural position (Figure 8).

\subsection{Apatite Fission Track Results}

A total of 12 samples (Table 4) contained sufficient apatite grains for AFT analysis: five samples belong to the KR-sampling line, three samples to the SM-sampling line, and four samples to the S-sampling line and the Gl-06 sampling location. The samples that passed the chi-square test (Table 4) have AFT central ages ranging between $50 \pm 3.2$ and $4.9 \pm 0.7 \mathrm{Ma}$, and their radial plots are shown in Figure 7. When comparing the AFT ages along-strike of the MMF, we notice progressively younger ages to the east (Figures 5 and 8). Samples located along the KR-sampling line near the western extend of the MMF, yield AFT central ages between $50.0 \pm 3.2$ (sample KR-08) and $41.8 \pm 1.9 \mathrm{Ma}$ (sample KR-01). AFT ages along the two sampling lines farther to the east vary between $32.6 \pm 4.0$ (sample SM-02) and $14.1 \pm 0.9 \mathrm{Ma}$ (sample SM-01) as well as $24.9 \pm 1.5$ (sample Gl-06) and $4.9 \pm 0.7 \mathrm{Ma}$ (sample S-11).

Overall, no clear differences in the AFT age distribution across the MMF seems to emerge, yet statistically more AFT ages are younger to the south of it (Figures 5 and 8). The data suggest that local variations of AFT ages are large and probably reflect cooling prior to, as well as during the development of the 

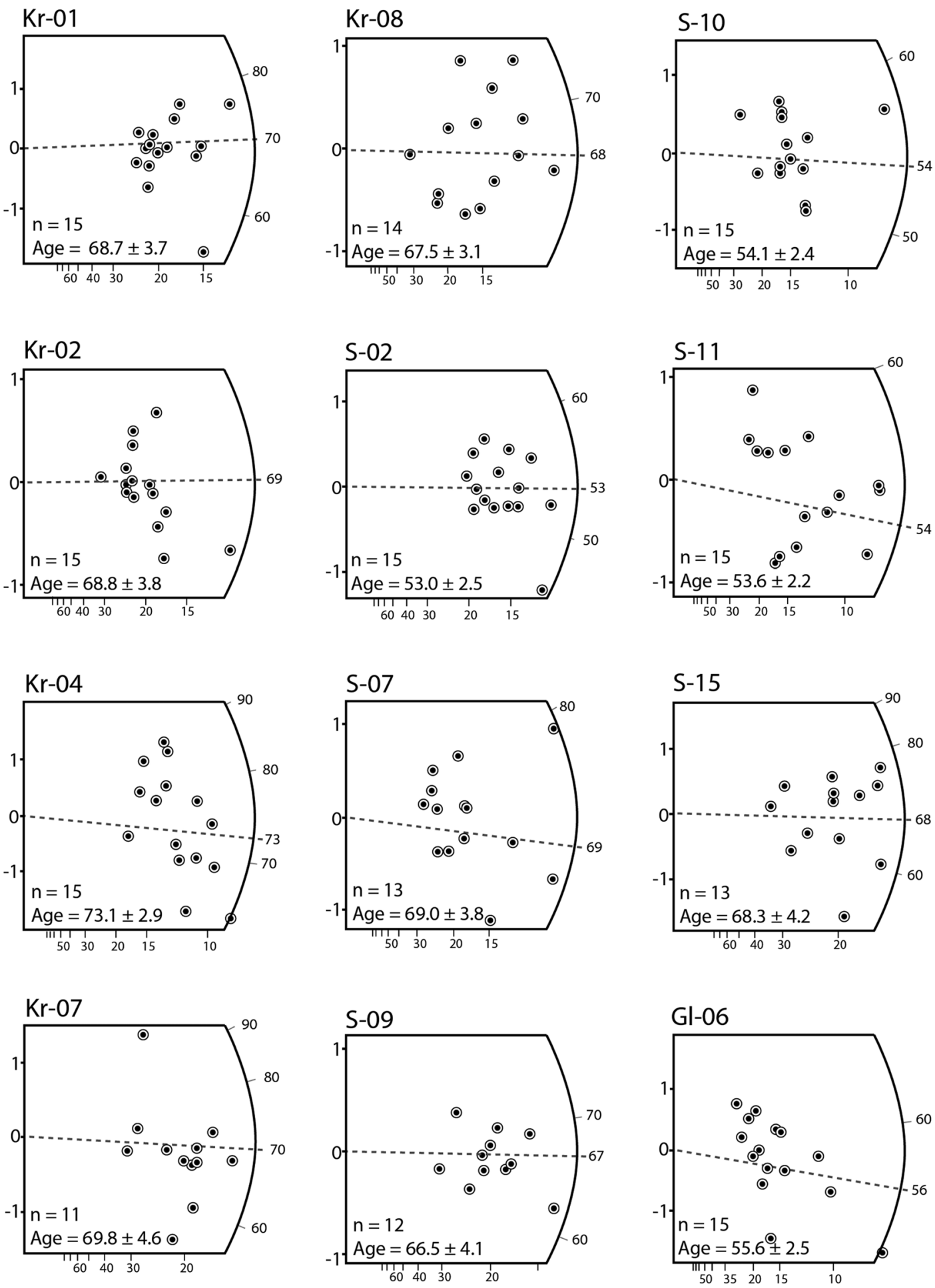

Figure 6. Radial plots showing the distribution of the measured ZFT cooling ages per sample. The dashed line in the radial plot indicates the obtained ZFT central age corresponding to the denoted age in the plot with the $1 \sigma$ standard error. The sample locations are shown in Figure 5 and listed in Table 2 with the analytical data presented in Table 3. Number of grains $(n)$.

complex Mur-Mürz fault system and associated tectonics within the Styrian block. Nevertheless, a first order analysis advocates an age difference between the western and eastern area of the MMF, with significant older ages in the west (Figures 5 and 8). 

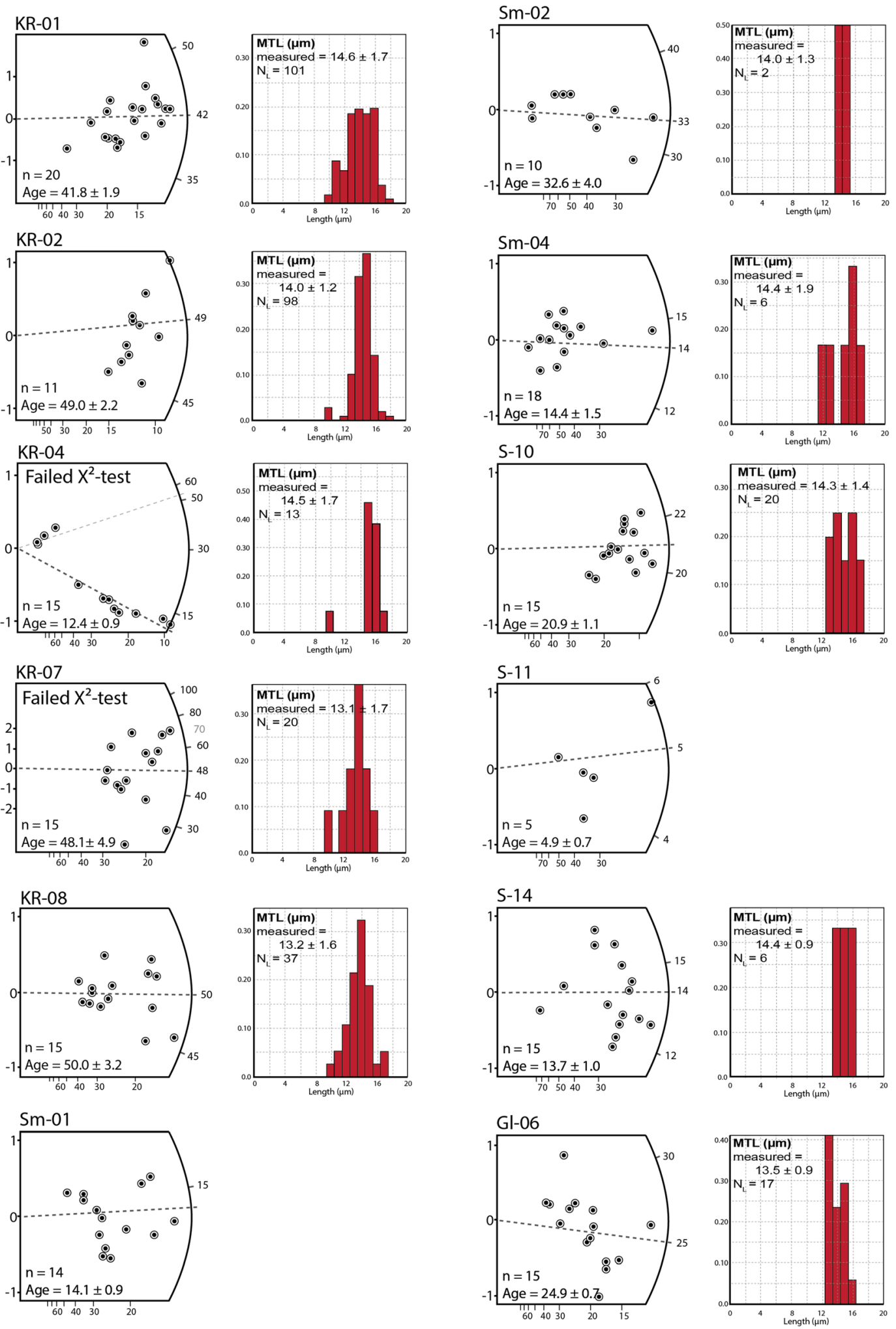

Figure 7. Radial plots showing the distribution of the measured AFT central ages per sample, along with the histograms indicating the distribution of track length measurements. The dashed line in the radial plot corresponds to the listed central AFT age with the $1 \sigma$ standard error. The light gray dashed line in the radial plot of KR-04 reflects the second age group. The sample locations are shown in Figure 5 and listed in Table 2 and accompanying analytical data are presented in Table 4. Number of grains $(n)$, mean track length (MTL), and number of measured lengths $\left(\mathrm{N}_{\mathrm{L}}\right)$. 


\section{Cross-section A}

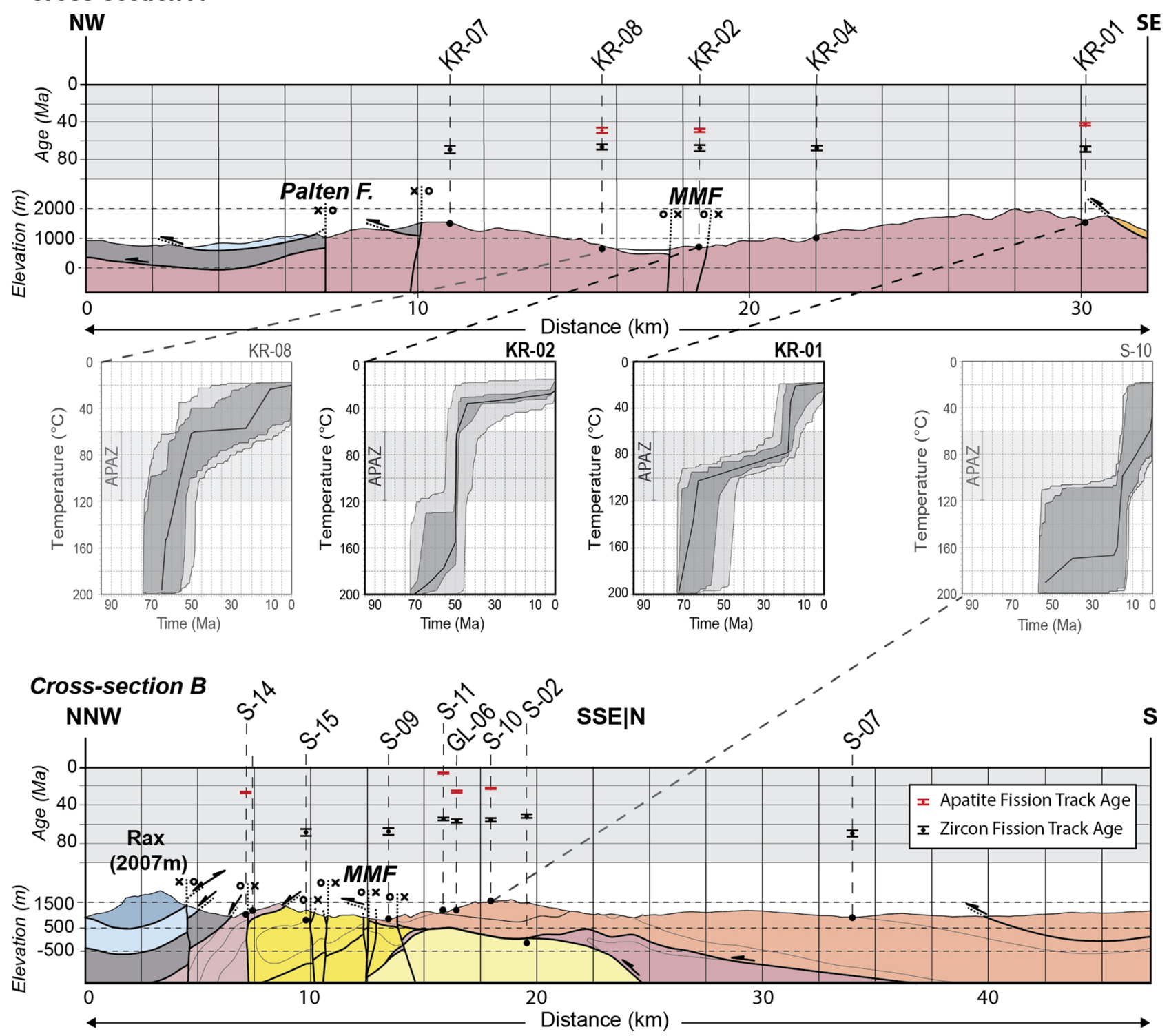

Figure 8. Age distribution of AFT and ZFT ages graphically displayed along cross sections A and B. The locations of the cross sections as well as the legend are shown in Figure 2. Below the cross sections the thermochronological modeling results are presented based on the ZFT and AFT cooling ages and apatite track length measurements. The light gray shaded area in the temperature-time graphs shows the $2 \sigma$ standard deviation, the dark gray area the $1 \sigma$ standard deviation, and the thick black line follows the temperature-time path of the most probable cooling trajectory. The apatite partial annealing zone (APAZ) is indicated by a shaded domain in each graph.

Two samples (KR-04 and KR-07) did not pass the chi-square test. Sample KR-07 still yields an AFT central age $(48.1 \pm 4.9 \mathrm{Ma})$ within the age range as described above for the KR-sampling line, whereas sample KR-04 has a central age of $12.4 \pm 0.9 \mathrm{Ma}$, which is significantly younger than the other central ages in the KRsampling line. Although the number of grains counted in sample KR-04 is limited $(n=15)$, two age groups of $\sim 54$ and $\sim 11.5 \mathrm{Ma}$ emerge in the radial plot (Figure 7). The two age groups correspond to the mean age trend along the western and the eastern part of the MMF, namely, Paleocene-Eocene ages (KR-sampling line) and Miocene ages (S-sampling line), respectively. We note that the samples that failed the chi-square test have not been used for further analysis or interpretations.

In two samples (KR-01 and KR-02) it was possible to measure about 100 confined track lengths, while in the other eight samples the number of measured FT lengths was insufficient for a statistical meaningful analysis (Figure 7 and Table 4). The measured FT lengths in both samples vary between 18 and $9 \mu \mathrm{m}$, whereby the 
Table 4

Apatite Fission Track Analytical Data

\begin{tabular}{|c|c|c|c|c|c|c|c|c|c|c|c|c|c|}
\hline \multirow{2}{*}{$\begin{array}{l}\text { Sample } \\
\text { code }\end{array}$} & \multirow[b]{2}{*}{$\mathrm{N}_{\mathrm{Gr}}$} & $\mathrm{N}_{\mathrm{s}}$ & $\rho_{\mathrm{s}}$ & $\mathrm{N}_{\mathrm{i}}$ & $\rho_{i}$ & $\mathrm{~N}_{\mathrm{d}}$ & \multirow{2}{*}{$\frac{\rho_{\mathrm{d}}}{\left(\times 10^{6} \mathrm{~cm}^{-2}\right)}$} & \multirow{2}{*}{$\begin{array}{l}\text { Age } \\
(\mathrm{Ma} \pm 1 \sigma)\end{array}$} & \multirow{2}{*}{$\frac{P\left(\chi^{2}\right)}{(\%)}$} & \multirow{2}{*}{$\begin{array}{l}\text { Disp. } \\
(\%)\end{array}$} & \multirow{2}{*}{$\begin{array}{l}\text { MTL } \\
\left(\mu \mathrm{m} \pm \mathrm{SD}_{\mathrm{L}}\right)\end{array}$} & \multirow[t]{2}{*}{$\mathrm{N}_{\mathrm{L}}$} & \multirow[t]{2}{*}{ Dpar } \\
\hline & & & $\left(\times 10^{6} \mathrm{~cm}^{-2}\right)$ & & $\left(\times 10^{6} \mathrm{~cm}^{-2}\right)$ & & & & & & & & \\
\hline $\mathrm{Kr}-01$ & 20 & 977 & 0.72 & 5216 & 3.84 & 25835 & 1.25 & $41.8 \pm 1.9$ & 99.58 & 0.00 & $13.62 \pm 1.72$ & 101 & 2.08 \\
\hline $\mathrm{Kr}-02$ & 11 & 1034 & 0.98 & 4709 & 4.46 & 25835 & 1.25 & $49.0 \pm 2.2$ & 99.25 & 0.00 & $14.04 \pm 1.24$ & 98 & 2.51 \\
\hline $\mathrm{Kr}-04$ & 15 & 237 & 0.19 & 4277 & 3.40 & 25835 & 1.25 & $12.4 \pm 0.9$ & 0.75 & 0.00 & $14.53 \pm 1.67$ & 13 & 2.66 \\
\hline $\mathrm{Kr}-07$ & 15 & 324 & 0.40 & 1580 & 1.95 & 25835 & 1.25 & $48.1 \pm 4.9$ & 0.01 & 0.29 & $13.05 \pm 1.71$ & 20 & 2.22 \\
\hline $\mathrm{Kr}-08$ & 15 & 378 & 0.51 & 1619 & 2.20 & 25835 & 1.25 & $50.0 \pm 3.2$ & 100.00 & 0.00 & $13.23 \pm 1.57$ & 37 & 1.99 \\
\hline S-10 & 15 & 575 & 0.48 & 6160 & 5.19 & 25835 & 1.25 & $20.9 \pm 1.1$ & 100.00 & 0.00 & $14.34 \pm 1.36$ & 20 & 2.01 \\
\hline S-11 & 5 & 56 & 0.14 & 2545 & 6.19 & 25835 & 1.25 & $4.9 \pm 0.7$ & 88.50 & 0.00 & - & - & - \\
\hline S-14 & 15 & 234 & 0.27 & 3819 & 4.36 & 25835 & 1.25 & $13.7 \pm 1.0$ & 99.89 & 0.00 & $14.37 \pm 0.85$ & 6 & 2.55 \\
\hline Gl-06 & 15 & 430 & 0.56 & 3117 & 40.79 & 20850 & 1.01 & $24.9 \pm 1.5$ & 99.95 & 0.00 & $13.46 \pm 0.92$ & 17 & 1.78 \\
\hline Sm-01 & 14 & 303 & 0.47 & 3870 & 5.96 & 20850 & 1.01 & $14.1 \pm 0.9$ & 99.99 & 0.00 & - & - & - \\
\hline Sm-02 & 10 & 84 & 0.26 & 465 & 1.45 & 20850 & 1.01 & $32.6 \pm 4.0$ & 100.00 & 0.00 & $13.99 \pm 1.33$ & 2 & 1.754 \\
\hline Sm-04 & 18 & 103 & 0.07 & 1294 & 0.90 & 20850 & 1.01 & $14.4 \pm 1.5$ & 100.00 & 0.00 & $14.38 \pm 1.89$ & 6 & 1.831 \\
\hline
\end{tabular}

Note. The presented AFT cooling ages are central ages with $1 \sigma$ standard error (Galbraith \& Laslett, 1993). The data are discussed in the text (see also Figures 8 and 10 and Table 2). $\mathrm{N}_{\mathrm{Gr}}=$ number of dated apatite crystals; $\rho_{\mathrm{d}}=$ dosimeter track density; $\mathrm{N}_{\mathrm{d}}=$ number of tracks counted on the dosimeter; $\rho_{\mathrm{d}}\left(\rho_{\mathrm{i}}\right)=\operatorname{spontaneous}$ (induced) track densities; $\mathrm{N}_{\mathrm{S}}\left(\mathrm{N}_{\mathrm{i}}\right)=$ number of spontaneous (induced) tracks counted; $P\left(\chi^{2}\right)=$ probability obtaining chi-square $\left(\chi^{2}\right)$ for $n-1$ degrees of freedom ( $\mathrm{n}$ is number of crystals); Disp. = dispersion in single-grain ages; $\mathrm{MTL}=\mathrm{C}$-axis projected mean track length with \pm the standard deviation $\left(\mathrm{SD}_{\mathrm{L}}\right)$; $\mathrm{N}_{\mathrm{L}}=$ number of measured confined tracks; Dpar = average etch pit diameter.

distribution is evenly spread in sample KR-01 and most of the FT lengths scatter around $14 \mu \mathrm{m}$ in sample KR-02. The mean confined track lengths (MTL) are $14.6 \pm 1.7 \mu \mathrm{m}$ for sample KR-01 and $14.0 \pm 1.2 \mu \mathrm{m}$ for sample KR-02.

\section{Thermal History Modeling}

The measured AFT ages and FT lengths of samples KR-01 and KR-02 are used as input for the inverse thermal history models. The annealing equations by Ketcham (2005) were used to constrain the apatite partial annealing zone (APAZ) and to model the measured AFT track length distributions (see the shaded areas in the T-t graphs in Figure 8). Besides using the AFT data as input for the inverse modeling, we also used the ZFT central age per sample; $68.7 \pm 3.7$ Ma for sample KR-01 and $68.8 \pm 3.8$ Ma for sample KR-02 (Figure 6 and Table 3). The ZFT central ages are associated with a closure temperature and a zircon partial retention zone (ZPRZ) between 250 and $200^{\circ} \mathrm{C}$ (e.g., Tagami \& Shimada, 1996). Thus, for the ZFT systems we used the lower bound of the $\mathrm{ZPRZ}$ as input for the models.

The two thermochronological models of KR-01 and KR-02 are presented in Figure 8 and show two distinct cooling phases. In sample KR-02 an elevated cooling rate is observed between 70 and $50 \mathrm{Ma}$. Thereafter, the sample cooled slowly from near surface conditions to its present location. KR-01 also records rapid cooling from 75 to ca. $60 \mathrm{Ma}$, followed by a prolonged period of slow cooling until $20 \mathrm{Ma}$ during which annealing of the fission tracks took place. Fast cooling resumed at ca. $20 \mathrm{Ma}$ and lasted until ca. $15 \mathrm{Ma}$.

Despite the insufficient number of FT length measurements on the other samples we still performed thermal history modeling to obtain a rough indication for regional cooling events by comparison with the two valid models. Sample KR-08 with 37 measured track lengths has a MTL of $13.2 \pm 1.6 \mu \mathrm{m}$ and is in line with the thermal history model of sample KR-02, while S-10 with 20 measured track length and a MTL of $14.3 \pm 1.4 \mu \mathrm{m}$ (Figure 7 and Table 4) is in line with the thermal history model of sample KR-01 (Figure 8).

After the initial phase of latest Cretaceous to earliest Paleocene fast cooling a period of slow cooling is observed in the thermochronological models. The models suggest cooling rates of approximately $1.5^{\circ} \mathrm{C} / \mathrm{Myr}$ up to $2.0^{\circ} \mathrm{C} / \mathrm{Myr}$ for the phase of slow cooling. This phase started in the Paleocene and continued until the early Miocene. The second phase of rapid cooling is only well constrained by one sample and lasted from the early to the middle Miocene and portrays rock cooling from approximately $80{ }^{\circ} \mathrm{C}$ to surface temperature $\left(20^{\circ} \mathrm{C}\right)$ at rates of ca. $14^{\circ} \mathrm{C} / \mathrm{Myr}$ during a period of ca. $5 \mathrm{Myr}$. The temperature decrease is 
equivalent to removing $\sim 2-3 \mathrm{~km}$ of overlying crust assuming a geothermal gradient of approximately 20-30 ${ }^{\circ} \mathrm{C} / \mathrm{km}$ for Miocene to recent times (Sachsenhofer, 2001).

\section{Cooling Pattern Variations in the Eastern Alps}

The presented ZFT and AFT cooling ages and thermal history modeling results highlight the complex cooling history of the eastern part of the Austroalpine units that followed the early Late Cretaceous regional metamorphism (e.g., Hoinkes et al., 1999; Neubauer et al., 1995; Schuster et al., 2001). Based on literature data, cooling to below the ZFT closure temperature $\left(\sim 220^{\circ} \mathrm{C}\right)$ already occurred during the Campanian to middle Paleocene (e.g., Thöni, 1999; and references therein) and below the AFT closure temperature during the Eocene (e.g., Hejl, 1997). Exceptions to this overall cooling pattern are the surroundings of the Rechnitz window (Cao et al., 2013; Dunkl \& Demény, 1997) and the Pohorje mountains (Fodor et al., 2008), where greenschist facies conditions lasted in the Austrolapine and underlying Penninic units until Miocene time. Subsequently these areas were exhumed rapidly during the early and middle Miocene (Cao et al., 2013; Dunkl \& Demény, 1997). Furthermore, based on AFT cooling ages a strong contrast in cooling history is revealed between the younger Niedere Tauern (23-14 Ma;Hejl, 1997 ; Wölfler et al., 2016) and the older Gurktal block (35-29 Ma, Hejl, 1997), separated by the Niedere Tauern fault (NTF, Figure 1). Young cooling of the Niedere Tauern block is also confirmed by apatite (U-Th)/He ages clustering around 6 Ma (Wölfler et al., 2016).

Our ZFT cooling ages suggest a similar diachronous cooling of the Austroalpine units as described above, such that cooling below the ZFT closure temperature in the western parts of the study area (Seckauer Tauern and Gleinalpe area) already occurred during the Maastrichtian and in the eastern part (surrounding the Wechsel and Rechnitz windows) during the latest Paleocene to early Eocene (Figure 5). The boundary between these two areas is indicated by the green line in Figure 5 and traces the Anger-Piregg fault and the thrust fault in its northern continuation. For the area to the west of this line the ZFT cooling ages range between 73 and $61 \mathrm{Ma}$, while in the area to the east ZFT ages are mostly 15-10 Myr younger, scattering between 69 and $53 \mathrm{Ma}$ (Figure 10a).

The age variations of the presented and previously published AFT cooling ages are consistent with the alongstrike trend of ZFT cooling ages and reveal no age trend across the MMF (Figure 8). The along-strike variation of AFT cooling ages along the MMF is evident with younger AFT cooling ages in the east (24-5 Ma) compared to the west (60-12 Ma) (Figures 5 and 8). Equally young AFT ages (15-6 Ma) were reported from the Wechsel window by Dunkl (1992). The AFT ages display similar and younger cooling ages compared to the Niedere Tauern region. To emphasize these and other significant variations in AFT cooling ages across the Eastern Alps, a contour map with ages is presented in Figure 9. The data in the map were interpolated in ArcGIS using a nearest neighbor analysis following the procedure as described in Luth and Willingshofer (2008). Overall, the AFT age distribution for the Eastern Alps emphasizes the complex cooling evolution with distinct differences on a regional and local scale. The majority of the data portray pre-Oligocene cooling of Austroalpine basement. This includes the Gurktal block, the Koralpe and Seckauer Tauern regions, the western part of the MMF (this study), and the area around Sopron to the southeast of the Vienna basin (Figure 9). Thermal history modeling of samples from these regions consistently suggests that rapid cooling to near surface conditions occurred prior to ca. 35 Ma (Hejl, 1997; Wölfler et al., 2016, cooling trend 1 in Figure 10a of this study). This age distribution and cooling path characteristics is in line with Eocene (44-36 Ma) detrital AFT ages from sedimentary basins along the MMF (Dunkl et al., 2005) and the distribution of ZFT ages shown in Rosenberg et al. (2018) but contrasts with regions of rapid early to middle Miocene cooling. The latter entails the Niedere Tauern (Hejl, 1997; Wölfler et al., 2016), the Pohorje mountains (Fodor et al., 2008), the Rechnitz window (Dunkl \& Demény, 1997), and the Semmering area on either side of the MMF (this study). We note that in the Pohorje mountains and the Rechnitz window also the ZFT ages are early Miocene, describing together with the AFT ages a single, continuous cooling event since the early Miocene (cooling trend 3 in Figure 10a). AFT ages from the Semmering region, however, are distinctly younger (by ca. 30 Myr) than their ZFT counterparts, suggesting that these rocks experienced two distinct cooling phases (cooling trend 2 in Figure 10a) during the latest Cretaceous to Paleocene and the early to middle Miocene. The above implies three distinct cooling trends characterizing the Eastern Alps east of the Tauern window. The significance of these trends will be discussed below in light of the regional and local deformation and tectonics. 


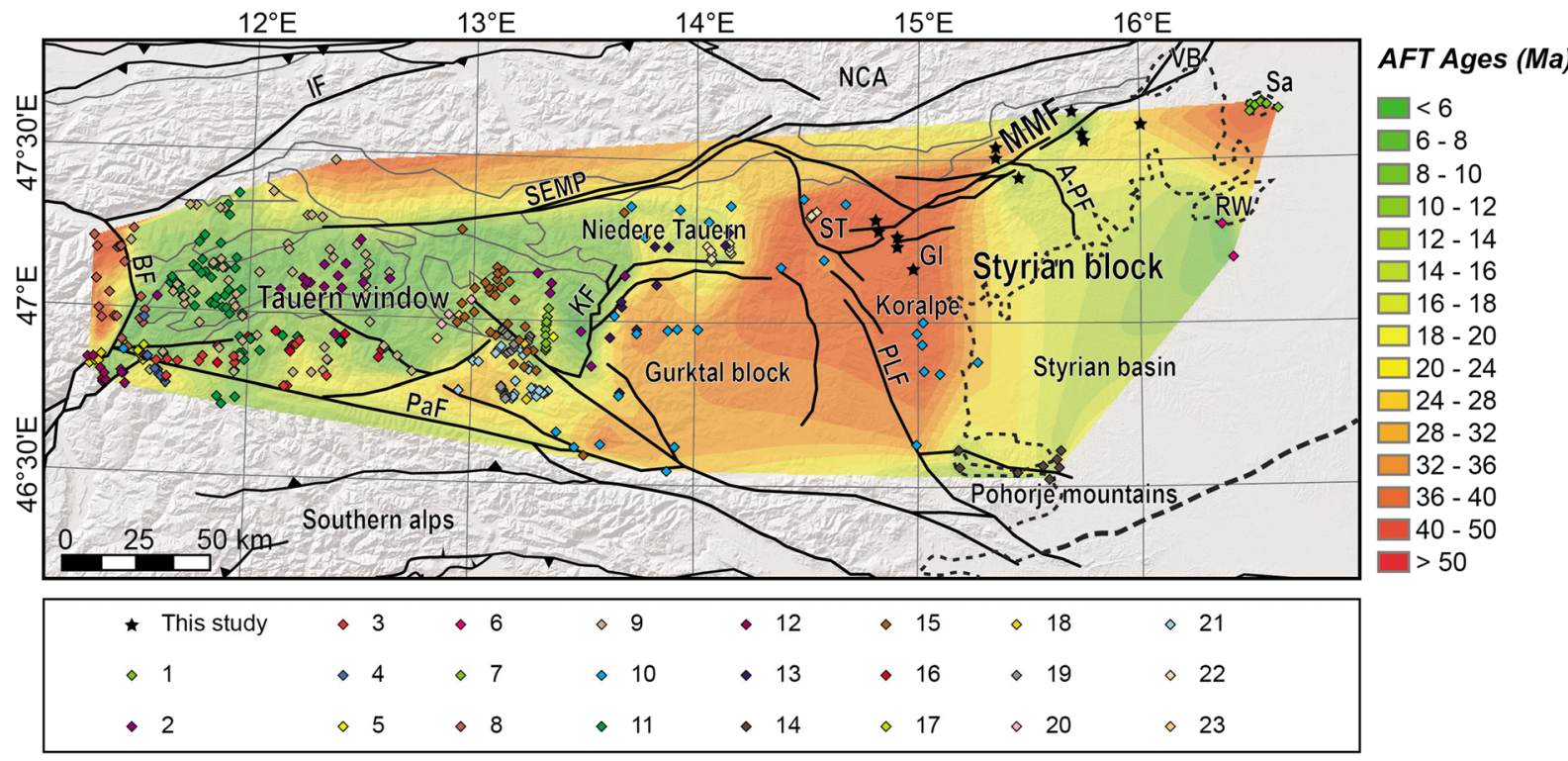

Figure 9. Distribution of AFT cooling ages across the Eastern Alps. The map is based on our new data and published data. (1) Balogh and Dunkl (2005), (2) Bertrand et al. (2015), (3) Coyle (1994), (4) Di Fiore (2013), (5) Dunkl et al. (2005), (6) Dunkl and Demény (1997), (7) Foeken et al. (2007), (8) Fügenschuh et al. (1997), (9) Grundmann and Morteani (1985), (10) Hejl (1997), (11) Most (2003), (12) Pomella et al. (2011), (13) Reinecker (2000), (14) Sachsenhofer et al. (1998), (15) Staufenberg (1987), (16) Steenken et al. (2002), (17) Stöckhert et al. (1999), (18) Viola et al. (2001), (19) Wölfler et al. (2008), (20) Wölfler et al. (2012), (21) Wölfler et al. (2015), (22) Wölfler et al. (2016), and (23) Zattin et al. (2007). Interpolation of the data was done following the procedure described in Luth and Willingshofer (2008). Anger-Piregg fault (A-PF), Periadriatic fault (PaF), Pöls-Lavanttal fault (PLF), Salzach-Ennstall-Mariazell-Puchberg fault (SEMP), Mur-Mürz fault (MMF), Brenner normal fault (BF), Katschberg normal fault (KF), Northern Calcareous Alps (NCA), Seckau Tauern (ST), Gleinalpe area (Gl), Wechsel window (WW), Sopron area (Sa), and Rechnitz window (RW).

\section{Discussion}

In this section the latest Cretaceous to recent evolution of the Eastern Alps is discussed, integrating structural and thermochronological data. Three time intervals, summarized in Figure 10, are highlighted: (1) pre-extrusion tectonics and vertical motions during the Paleocene to earliest Miocene, (2) syn-extrusion tectonics during the Miocene, and (3) post-extrusion inversion and young exhumation since late Miocene time.

\subsection{Pre-Extrusion Tectonics and Vertical Motions (>17 Ma)}

An in-depth discussion of the structural and topographic evolution of the Eastern Alps for the time span after the Cretaceous orogeny and the onset of lateral extrusion is beyond the scope of this contribution, we nevertheless wish to highlight a few events relevant for the interpretation of the new data.

Our zircon fission track data document post $\sim 80 \mathrm{Ma}$ cooling to below $\sim 220^{\circ} \mathrm{C}$ and are in agreement with the general idea of rapid cooling of Austroalpine units after their metamorphic peak in the early Late Cretaceous (Neubauer et al., 1995; Rosenberg et al., 2018; Thöni, 1999; and references therein). Cooling was coeval with orogen-parallel extension and erosion (Froitzheim et al., 2008; Willingshofer et al., 1999). Extension was accommodated by penetrative E-directed deformation in deeper structural levels and along major normal faults that developed at high angle to the earlier formed thrust structures. The latter include the normal faults at the western (Neubauer et al., 1995) and eastern (Krenn et al., 2008) margin of the Paleozoic of Graz (Figures 2 and 5).

Cooling of Autroalpine units in our study area continued during the Paleocene to early Miocene at low rates, in the order of $1.5-2{ }^{\circ} \mathrm{C} / \mathrm{Myr}$ (Figures 8 and 10a). Assuming a geothermal gradient of $25^{\circ} \mathrm{C} / \mathrm{km}$, our ZFT data suggest that the presently exposed Austroalpine rocks have already been at upper crustal level ( $\sim \mathrm{km}$ depth) since the Paleocene. Furthermore, as most of our AFT ages record pre-extrusion cooling of rocks, we argue that regional cooling and exhumation of rocks to depths of about $4 \mathrm{~km}$ occurred prior to ca. $20 \mathrm{Ma}$. With the exception of the Gurktal block, which records rapid cooling during the latest Eocene-early Oligocene (Hejl, 1997), the slow cooling of Austroalpine units is in agreement with low erosion rates (Kuhlemann et al., 2006), and the formation of peneplains, that is, the Dachstein paleosurface, which is subsequently overlain 

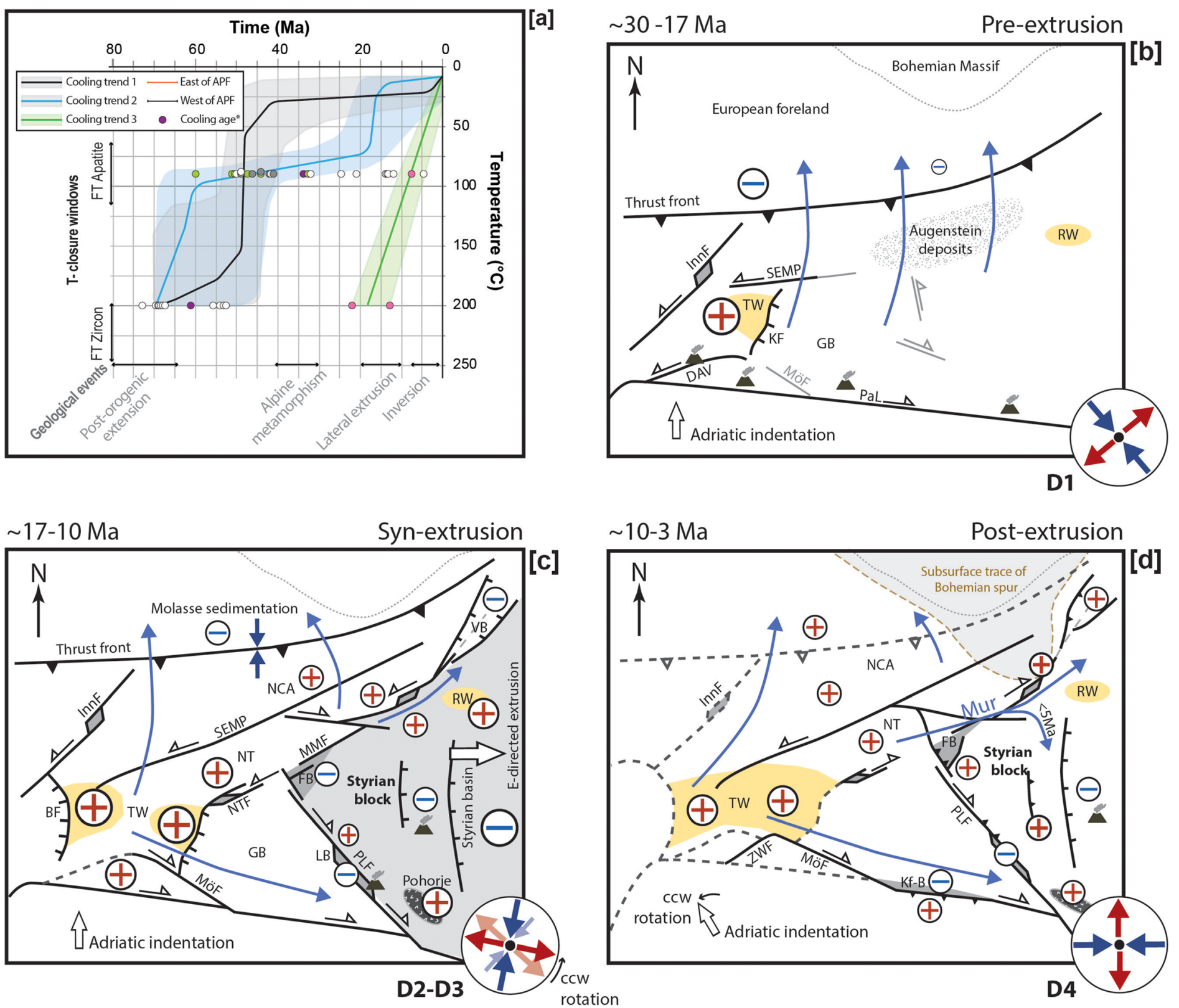

Figure 10. Overview of the temperature-time (a) and the tectonic evolution of the study area (b-d). The three consecutive time steps illustrate the active faults (black lines), early stage activation of faults (gray lines), deactivated faults (dashed lines), and drainage patterns (blue arrows) according to Kuhlemann et al. (2001) as well as intramontane basins (dark gray shaded areas). Vertical motions (undifferentiated) are indicated by either a plus or minus symbol (the larger the symbol, the higher the relative uplift and subsidence, respectively, non-scaled). The illustrations are based on graphics presented in Favaro et al. (2015), Wölfler et al. (2011), and Frisch et al. (1998). (a) Summary of zircon and AFT cooling ages form the study region displayed on top of potential cooling paths predicted for the Austroalpine unit, also shown in Figure 8 (cooling trends 1 and 2), and expected for the Penninic unit exposed in the Rechnitz window (cooling trend 3). Note that ZFT ages are plotted at the lower temperature end of the partial retention zone to obtain conservative minimum estimates for cooling rates. Color coding for the age symbols is the same as in Figure 5. (b-d) Cartoons summarizing key features related to the (a) pre-, (b) syn-, and (c) post-tectonic evolution of the Eastern Alps. Tauern window (TW), Niedere Tauern (NT), Rechnitz window (RW), Northern Calcareous Alps (NCA), Katschberg normal fault (KF), Brenner normal fault (BF), Inntal fault (InnF), Niedere Tauern fault (NTF), Defereggen-Antholz-Vals fault (DAV), Mur-Mürz fault (MMF), Mölltal fault (MF), Periadriatic fault (PaF), Pöls-Lavanttal fault (PLF), Salzach-Ennstal-Mariazell-Puchberg fault (SEMP), Gurktal block (GB), Fohnsdorf basin (FB), Lavanttal basin (LB), Vienna basin (VB), and Klagenfurt basin (KB).

by the Augenstein Formation (Frisch et al., 2001). The above mentioned data and observations suggest that no mountainous landscape evolved east of the Tauern window until the Late Miocene (Frisch et al., 1998) and that rapid Oligocene to Miocene rock exhumation and topography formation is largely confined to 
the area of the future Tauern window and its surroundings (Figure 10b) (e.g., Bartosch et al., 2017; Frisch et al., 1998; Kuhlemann, 2007; Luth \& Willingshofer, 2008; Rosenberg et al., 2018; Scharf et al., 2016).

This evolution of Austroalpine units east of the Tauern window is compatible with our fault slip data, which show that D1 occurred under strike-slip deformation conditions, calling for oblique convergence between Europe and the evolving mountain belt. We argue that the NNW-SSE shortening direction of D1 was not favorable for activating the MMF as sinsitral strike-slip fault. Therefore, we propose that D1 predates the segmentation of the Alpine nappe stack and thus the formation of the Styrian block. D1 kinematics are consistent with shortening directions deduced from the Northern Calcareous Alps (Peresson \& Decker, 1997a) and thin-skinned thrusting at the transition of the Eastern Alps and Western Carpathians (Granado et al., 2016). NNW-SSE contraction was associated with ENE-WSW extension, leading to rapid exhumation of the Penninic units exposed in the Rechnitz window since 23 Ma (Cao et al., 2013; Dunkl \& Demény, 1997). This suggests that the easternmost Alps are affected by extension prior to the main phase of lateral extrusion.

The disparities between the eastern Eastern Alps (slow cooling, low erosion rates) and the western Eastern Alps (rapid cooling, high erosion rate) insinuate that the east was not affected by significant Cenozoic crustal thickening. Possible reasons for that are sought in the lateral variations of the amount of shortening (twice as much in the west than in the east) in combination with the inherited shape of the subducted European plate (Rosenberg et al., 2018).

\subsection{Syn-Extrusion Tectonics at the Eastern Margin of the Eastern Alps (17-10 Ma)}

The presented D2 to D3 deformation phases along the MMF are interpreted to coincide with lateral extrusion and in particular with the eastward escape of the Styrian block, along the MMF and the conjugate PLF (Figures 1 and 10c) during the middle Miocene, facilitated by the opening of the Pannonian basin (Horváth et al., 2006).

Our D2 was probably coeval with the opening of sedimentary basins (e.g., Mürztal basin, Leoben basin, and Seckau basin) at strike-slip step overs with dominantly N-S striking normal faults. D3 marks the deformation phase that is compatible with the activation of the (E)NE-(W)SW trending sinistral MMF and conjugate NNW-SSE trending dextral faults (Figure 10c). Although the MMF marks a prominent feature in the landscape as a consequence of the along-strike formation of pull-apart basins and the incision of the Mur and Mürz rivers, it does not form a continuous fault but is characterized by a multitude of fault segments. For example, the faults between Leoben and Mürzzuschlag (Figure 2) clearly illustrate the complex interference of sinistral and dextral strike-slip faults in combination with basin formation. As such, fault formation along the MMF was associated with the development of multiple fault segments with variable offsets confining small crustal fragments, similar to the PLF (Brosch \& Pischinger, 2014; Pischinger et al., 2008). We argue that the complex evolution of the fault then leads to the wide spread of the presented AFT cooling ages (50 to 4.9 Ma, Figure 5) as a consequence of differential exhumation of individual fault-bounded blocks.

Overall, differential vertical motions across the MMF must have been small as no systematic and significant differences in cooling ages are detectable by our ZFT and AFT cooling ages (Figures 8 and 9). This is in agreement with our field results, which underline the predominance of strike-slip faulting, suggesting that the MMF did not play a significant role for the surface uplift of the Styrian block. In particular, we find that syn-extrusion cooling ages pertain to basement blocks that are in between fault segments (e.g., samples Sm-04 or Sm-01, Figure 5). Such aerially confined uplifting regions can be explained by the development of local transpression in between Riedel shears as demonstrated by analogue modeling studies (Dooley \& Schreurs, 2012; Leever et al., 2011). Our findings from the MMF are in line with results deduced from paleo-landscape studies, which show that Austroalpine units north and south of the sinistral SEMP share a common uplift history, implying that south side up vertical motions across the central segment of the SEMP were minor (Dertnig et al., 2017).

The Styrian block is classically viewed as a rigid block escaping to the east (e.g., Linzer et al., 2002). However, the segmented nature of the MMF and the distribution of AFT cooling ages do not support uniform behavior of that block. Furthermore, as illustrated in Figure 10c, the Styrian block was affected by vertical and horizontal motions, during the latest early and middle Miocene, where horizontal displacement vectors dominate along the bounding strike-slip faults and vertical motions mainly affect the interior of the block. These include (i) rapid subsidence of the extensional Styrian basin associated 
with rift related volcanism (Sachsenhofer et al., 1997), (ii) rapid cooling and exhumation of the Pohorje and Koralpe mountains (Fodor et al., 2008; Legrain et al., 2014), (iii) gradual uplift and erosion of the Koralpe range (Pischinger et al., 2008; Wagner et al., 2010), and (iv) rapid exhumation of the Penninic unit in the Rechnitz window along a low-angle detachment fault (Cao et al., 2013; Dunkl \& Demény, 1997). These data suggest that the entire block displays a noncoherent behavior and cannot be considered as a rigid escaping crustal block. This view is in line with lithosphere-scale analogue experiments, which predict complex fault zone development of major sinistral faults bounding extruding blocks where the displacement of particles is sub-parallel to the fault strike, promoting almost pure strike-slip faulting with minor topography development along the fault (Van Gelder et al., 2017). Additionally, numerical landscape evolution models that take structures such as the MMF and the PLF into account predict that fault activity facilitates the development of relief but decreases the net elevation gain in the area of the active faults (Bartosch et al., 2017; Robl, Stüwe, et al., 2008). At the same time, the formation of the MMF also impacted on the evolution of the drainage system, which changed from north draining, into the Molasse basin during the pre-extrusion period to fault parallel during the extrusion period (Frisch et al., 1998; Kuhlemann et al., 2006; Robl, Hergarten, et al., 2008).

\subsection{Post-Extrusion Inversion and Young Uplift}

The main phase of lateral extrusion in the Eastern Alps was followed by widespread surface uplift of the Alpine mountain belt, its northern foreland, and the western margin of the Pannonian basin during the Late Miocene to Quaternary (e.g., Beidinger \& Decker, 2014; Ebner \& Sachsenhofer, 1995; Kurz et al., 2011; Neubauer \& Unzog, 2003; Sachsenhofer et al., 2000; Zeilinger et al., 1999). The amount of uplift was inferred to be in the order of several hundreds of meters in the Vienna and Styrian basins (Peresson \& Decker, 1997a; Sachsenhofer et al., 1997), with estimates not exceeding $500 \mathrm{~m}$ in the foreland basin (Genser et al., 2007). Inversion of the intramontane basins like the Lavanttal or the Fohnsdorf basin is accommodated by reactivation of their main boundary faults (Figure 10d, Kurz et al., 2011).

Large-scale uplift and erosion of the Alpine realm is also reflected in increased sediment discharge since 6 Ma (Kuhlemann et al., 2001) as well as increased incision rates indicating a regional young uplift of the MMF and surroundings including the Northern Calcareous Alps. Detailed analysis of geomorphic markers including planation surfaces, river terraces, and cave levels suggests that the Styrian block was uplifted en block by about $600 \mathrm{~m}$ during the past 5 Myr (Legrain et al., 2015; Wagner et al., 2010).

Within the frame of overall uplift and enhanced erosion, differential vertical motions on a smaller scale impacted on the course of the drainage systems. For example, prior to $5 \mathrm{Ma}$ the Mur River drained into the Vienna basin (Figure 10d; Kuhlemann et al., 2006; Dunkl et al., 2005) or into the Styrian basin via the Feistritz valley (Schuster et al., 2016). However, after 5 Ma the river changed course and the current drainage (toward Graz) was established leading to an increase in sediment discharge from the Eastern Alps into the Styrian basin (Kuhlemann et al., 2002). In this context, we link our youngest phase of deformation (D4), which documents E-W shortening, to the Late Miocene to Pliocene inversion, which occurs within a frame of overall N-S convergence (Handy et al., 2010). This inversion could also explain the very young AFT ages recorded along the eastern extend of the MMF; that is, sample S-11 (Figure 5) and the Wechsel window (Dunkl, 1992).

Tectonic driving mechanism for the inversion and young uplift are still poorly understood. Proposed mechanisms include (1) the locking of subduction at the Carpathian deformation front (Peresson \& Decker, 1997a) leading to the stagnation of back-arc extension, (2) delamination of the lithospheric mantle (Genser et al., 2007) and/or slab-breakoff (Legrain et al., 2015), (3) flank uplift in the order of several hundred meters that was predominantly related to lateral heat transport during the post-rift evolution of the Pannonian basin (Balázs et al., 2017), or (4) an increase in orogenic wedge-foreland coupling (Willingshofer \& Sokoutis, 2009), which leads to major uplift of the orogenic wedge at distance of $\sim 70-100$ $\mathrm{km}$ from the orogenic front. We note that the current distance between the Alpine thrust front and the study region is in the order of $60 \mathrm{~km}$. Additionally, the latter mechanism has also been proposed for the Late Miocene exhumation phase south of the Klagenfurt basin (Heberer et al., 2016).

Mechanisms one and three are strongly tied to the dynamic and rheological evolution of the Pannonian basin and rely on the effectiveness of strain transfer from the Carpathian front across the weak 
Pannonian lithosphere or the magnitude of heat transfer from the center of the basin, which was inferred to be in the order of a few hundred meters based on numerical simulations (Balázs et al., 2017).

Numerical modeling studies predict that surface uplift in response to deep-seated process such as slab detachment (mechanism two) occurs over areas of $\sim 100-300 \mathrm{~km}$ and with amplitudes of a few kilometers for shallow to intermediate depth (50-200 km) breakoff (Duretz et al., 2011). In the Eastern Alps, east of the Tauern window, Qorbani et al. (2015) interpret shear wave splitting data in terms of a discontinuous slab that detached form the subducting European plate at a depth of $\sim 70 \mathrm{~km}$. As such delamination of the lithospheric mantle is probably a viable mechanism to explain the post Miocene uplift of the foreland basin (Genser et al., 2007) and at least contributed to the large-scale uplift of the Eastern Alps, on a similar scale to the Western Alps (Baran et al., 2014).

Although the above listed mechanisms can account for regional uplift, they lack detail to adequately account for localized uplift of the Semmering area. Ratschbacher, Frisch, et al. (1991) interpreted this region in terms of a restraining bend (the "Semmering pull-up") and established a causative relation to the Bohemian massif. Along these lines we therefore suggest that underthusting of the Bohemian basement spur located beneath the Eastern Alps-Pannonian basin transition (Reinecker \& Lenhardt, 1999) could be essential for the localized uplift of the overlying region, which ultimately lead to a change in the course of the Mur river and triggered increased incision rates (Figure 10d). At present, the tip of the Bohemian spur is located below the Semmering pass (Figure 10d), and its outline is portrayed by P-wave velocity data (Grad et al., 2009) and seismic activity (Baroň et al., 2019; Reinecker \& Lenhardt, 1999) suggesting that the Bohemian spur is still acting as a buttress. Geometrically the Bohemian spur would be a rigid bulge on the downgoing plate, mechanically similar, yet shallower in the lithosphere, to what was described by Bendick and Ehlers (2014) for the deformation of curved plates at orogenic syntaxes. For such settings, localized uplift of the overriding plate with a characteristic "bulls-eye" shaped cooling and exhumation pattern is predicted. This mechanism might be able to explain the localized cooling and uplift of the Austroalpine orogenic wedge in the Semmering region and the Northern Calcareous Alps starting at ca. $5 \mathrm{Ma}$ as well as the change in dewatering direction of the paleo-Mur and the birth of the Mürz river. However, more low-temperature thermochronology data would be needed to map out the uplifting region in more detail. This buttressing effect of the Bohemian spur, which probably started to affect the evolution of the eastern Eastern Alps already in the middle Miocene, is thought to be the main reason for the changing strike of thrust sheets from dominant E-W to NE-SW (Ratschbacher, Frisch, et al., 1991). It also might explain the differential uplift of the area north of the MMF where paleosurfaces are at higher elevation by $400 \mathrm{~m}$ (Schuster et al., 2016) compared to the Semmering area south of it. In addition, we suggest that the stagnation of back-arc extension in the Pannonian basin, which hampers lateral extrusion, together with counter clockwise rotation of Adria could provide the sufficient changes in boundary conditions to obtain E-W directed shortening and large-scale uplift of the easternmost part of the Alps.

\section{Conclusion}

We have presented new ZFT and AFT cooling ages from the Eastern Alps east of the Tauern window together with a fault slip analysis along a major Miocene strike-slip fault, namely, the Mur-Mürz fault (MMF). The integrated thermochronological data and field kinematics provide new insights in the tectonic evolution of the eastern Eastern Alps summarized in three consecutive time steps.

1. Following on Late Cretaceous to Paleocene cooling of Austroalpine nappes below the closure temperature of the ZFT system, slow (ca. $1.5-2.0^{\circ} \mathrm{C} / \mathrm{Myr}$ ) Eocene to early Miocene cooling suggests that exhumation of the Austroalpine rocks at the eastern termination of the Alps occurred at low rates. This is in agreement with large-scale peneplanation and low erosion rates east of the Tauern window and a stress regime that favors strike-slip deformation in the area of the future MMF (D1) with an overall NNW-SSE shortening direction. Our new AFT data suggest that within our study area the majority of the presently exposed rocks of the Austroalpine unit east of the Tauern window were at shallow crustal level $(<\sim 4 \mathrm{~km})$ at the onset of lateral extrusion.

2. Lateral extrusion during the middle Miocene is accompanied by rapid exhumation of the Tauern window, the Niedere Tauern area, the Rechnitz window, and Pohorje mountains but did not lead 
to significant differential vertical motions across the MMF as shown by overall similar apatite fission track ages on either side of the fault. This is in agreement with our field kinematics (D2 and D3) that demonstrates dominant strike-slip deformation during the extrusion of the Styrian block. The inferred shortening direction is compatible with the sinistral activation of the MMF and is linked to the main phase of lateral extrusion. The MMF represents a strongly segmented fault, along which exhumation of fault blocks occurred on a local scale, contributing to the large scatter of AFT cooling ages.

3. (D4) is characterized along the MMF by a strike-slip deformation regime with E-W contraction and has caused the reactivation of sinistral as dextral and normal as thrust faults. This phase of deformation is probably trelated to the inversion of basins along the MMF and the western Pannonian basin. The AFT cooling ages suggest that local enhanced exhumation of rocks is embedded within a phase of orogen-scale uplift. We speculate that this is due to the combined effect of the underthrust Bohemian spur and locking of the Carpathian subduction system and the related stagnation of Pannonian backarc extension at large.

\section{Acknowledgments}

The authors acknowledge the thorough reviews by Eva Enkelmann, Kurt Stüwe, and the associate editor Djordje Grujic, which helped to significantly improve the manuscript. We thank Helen King for improving the English of the manuscript. I. van Gelder, E. Willingshofer, and D. Sokoutis are indebted to Kurt Decker for introducing us to the MMF in the Semmering region. This work was funded by the Dutch Centre of Integrated Solid Earth Sciences. Data supporting this paper are available through GFZ data services (van Gelder et al., 2020).

\section{References}

Angelier, J. (1989). From orientation to magnitude in paleostress determinations using fault slip data. Journal of Structural Geology, 11(1-2), 37-50.

Angelier, J. (1994). Inversion of brittle tectonic data in order to determine stress tensors-faults, non-faults and pressure tension structures. Bulletin de la Societe Geologique de France, 165(3), 211-220.

Balázs, A., Burov, E., Matenco, L., Vogt, K., Francois, T., \& Cloetingh, S. (2017). Symmetry during the syn- and post-rift evolution of extensional back-arc basins. Earth and Planetary Science Letters, 462, 86-98. https://doi.org/10.1016/j.epsl.2017.01.015

Balogh, K., \& Dunkl, I. (2005). Argon and fission track dating of Alpine metamorphism and basement exhumation in the Sopron Mts. (Eastern Alps, Hungary): Thermochronology or mineral growth? Mineralogy and Petrology, 83(3-4), 191-218.

Baran, R., Friedrich, A. M., \& Schlunegger, F. (2014). The Late Miocene to Holocene erosion pattern of the Alpine foreland basin reflects Eurasian slab unloading beneath the western Alps rather than global climate change. Lithosphere, 6(2), 124-131. https://doi.org/ 10.1130/L307.1

Barbarand, J., Carter, A., Wood, I., \& Hurford, T. (2003). Compositional and structural control of fission-track annealing in apatite. Chemical Geology, 198(1-2), 107-137.

Baroň, I., Plan, L., Sokol, L., Grasemann, B., Melichar, R., Mitrovic, I., \& Stemberk, J. (2019). Present-day kinematic behaviour of active faults in the Eastern Alps. Tectonophysics, 752, 1-23. https://doi.org/10.1016/j.tecto.2018.12.024

Bartosch, T., Stüwe, K., \& Robl, J. (2017). Topographic evolution of the Eastern Alps: The influence of strike-slip faulting activity. Lithosphere, 9(3), 384-398.

Beidinger, A., \& Decker, K. (2011). 3D geometry and kinematics of the Lassee flower structure: Implications for segmentation and seismotectonics of the Vienna Basin strike-slip fault, Austria. Tectonophysics, 499(1-4), 22-40.

Beidinger, A., \& Decker, K. (2014). Quantifying Early Miocene in-sequence and out-of-sequence thrusting at the Alpine-Carpathian junction. Tectonics, 33, 222-252. https://doi.org/10.1002/2012TC003250

Bendick, R., \& Ehlers, T. A. (2014). Extreme localized exhumation at syntaxes initiated by subduction geometry. Geophysical Research Letters, 41, 5861-5867. https://doi.org/10.1002/2014GL061026

Bernet, M. (2009). A field-based estimate of the zircon fission-track closure temperature. Chemical Geology, 259(3-4), 181-189.

Bertrand, A., Rosenberg, C., \& Garcia, S. (2015). Fault slip analysis and late exhumation of the Tauern window, Eastern Alps. Tectonophysics, 649, 1-17.

Brosch, F. J., \& Pischinger, G. (2014). Small- to meso-scale brittle rock structures and the estimation of "paleostress" axes-A case study from the Koralm region (Styria/Carinthia). Austrian Journal of Earth Sciences, 107(2), 37-59.

Cao, S., Neubauer, F., Bernroider, M., Liu, J., \& Genser, J. (2013). Structures, microfabrics and textures of the Cordilleran-type Rechnitz metamorphic core complex, Eastern Alps. Tectonophysics, 608, 1201-1225.

Coyle, D. A. (1994). The application of apatite fission track analysis to problem in tectonics (PhD thesis). Victoria: La Trobe University.

Decker, K. (1996). Miocene tectonics at the Alpine-Carpathian junction and the evolution of the Vienna basin. Mitteilungen der Gesellschaft der Geologie- und Bergbaustudenten in Österreich, 41, 33-44.

Decker, K., Meschede, M., \& Ring, U. (1993). Fault slip analysis along the northern margin of the Eastern Alps (Molasse, Helvetic nappes, North and South Penninic flysch, and the Northern Calcareous Alps). Tectonophysics, 223(3-4), 291-312.

Decker, K., Peresson, H., \& Hinsch, R. (2005). Active tectonics and Quaternary basin formation along the Vienna basin transform fault. Quaternary Science Reviews, 24(3-4), 305-320.

Delvaux, D., Moeys, R., Stapel, G., Petit, C., Levi, K., Miroshnichenko, A., et al. (1997). Paleostress reconstructions and geodynamics of the Baikal region, Central Asia, Part 2. Cenozoic rifting. Tectonophysics, 282(1-4), 1-38.

Delvaux, D., \& Sperner, B. (2003). New aspects of tectonic stress inversion with reference to the TENSOR program. Geological Society, London, Special Publications, 212(1), 75-100.

Dertnig, F., Stüwe, K., Woodhead, J., Stuart, F. M., \& Spötl, C. (2017). Constraints on the Miocene landscape evolution of the Eastern Alps from the Kalkspitze region, Niedere Tauern (Austria). Geomorphology, 299, 24-38.

Di Fiore, G. (2013). Evoluzione morfotettonica delle aree alpine "Sempione" e "Brennero" attraverso studi termocronologici di bassa temperature (PhD thesis). Bologna: Universita di Bologna.

Donelick, R. A., Ketcham, R. A., \& Carlson, W. D. (1999). Variability of apatite fission-track annealing kinetics: II. Crystallographic orientation effects. American Mineralogist, 84, 1224-1234.

Dooley, T. P., \& Schreurs, G. (2012). Analogue modelling of intraplate strike-slip tectonics: A review and new experimental results. Tectonophysics, 574, 1-71. https://doi.org/10.1016/j.tecto.2012.05.030 
Dunkl, I. (1992). Final episodes of the cooling history of eastern termination of the Alps (pp. 137-139). IGP/KFU Graz: ALCAPA field Guide.

Dunkl, I. (2002). Trackkey: A windows program for calculation and graphical presentation of fission track data. Computers \& Geosciences, $28(1), 3-12$

Dunkl, I., \& Demény, A. (1997). Exhumation of the Rechnitz window at the border of the Eastern Alps and Pannonian basin during Neogene extension. Tectonophysics, 272(2-4), 197-211.

Dunkl, I., Kuhlemann, J., Reinecker, J., \& Frisch, W. (2005). Cenozoic relief evolution of the Eastern Alps—Constraints from apatite fission track age-provenance of Neogene intramontane sediments. Austrian Journal of Earth Sciences, 98, 92-105.

Duretz, T., Gerya, T. V., \& May, D. A. (2011). Numerical modelling of spontaneous slab breakoff and subsequent topographic response. Tectonophysics, 502(1-2), 244-256.

Ebner, F., \& Sachsenhofer, R. F. (1995). Paleogeography, subsidence and thermal history of the Neogene Styrian basin (Pannonian basin system, Austria). Tectonophysics, 242(1-2), 133-150.

Favaro, S., Schuster, R., Handy, M. R., Scharf, A., \& Pestal, G. (2015). Transition from orogen-perpendicular to orogen-parallel exhumation and cooling during crustal indentation-Key constraints from Sm-147/Nd-144 and Rb-87/Sr-87 geochronology (Tauern window, Alps). Tectonophysics, 665, 1-16.

Flügel, H. W., \& Neubauer, F. (1984). Geologische Karte der Steiermark, 1:200000. Vienna: Geologische Bundesanstalt.

Fodor, L. (1995). From transpression to transtension: Oligocene-Miocene structural evolution of the Vienna basin and the East AlpineWestern Carpathian junction. Tectonophysics, 242(1-2), 151-182.

Fodor, L., Gerdes, A., Dunkl, I., Koroknai, B., Pécskay, Z., Trajanova, M., et al. (2008). Miocene emplacement and rapid cooling of the Pohorje pluton at the Alpine-Pannonian-Dinaridic junction, Slovenia. Swiss Journal of Geosciences, 101(S1), 255-271. https://doi.org/ 10.1007/s00015-008-1286-9

Fodor, L., Jelen, B., Márton, E., Skaberne, D., Čar, J., \& Vrabec, M. (1998). Miocene-Pliocene tectonic evolution of the Slovenian Periadriatic fault: Implications for Alpine-Carpathian extrusion models. Tectonics, 17(5), 690-709.

Foeken, J. P. T., Persano, C., Stuart, F. M., \& ter Voorde, M. (2007). Role of topography in isotherm perturbation: Apatite (U-Th)/He and fission track results from the Malta tunnel, Tauern window, Austria. Tectonics, 26, TC3006. https://doi.org/10.1029/ 2006TC002049

Frisch, W., Dunkl, I., \& Kuhlemann, J. (2000). Post-collisional orogen-parallel large-scale extension in the Eastern Alps. Tectonophysics, 327(3-4), 239-265.

Frisch, W., Kuhlemann, J., Dunkl, I., \& Brügel, A. (1998). Palinspastic reconstruction and topographic evolution of the Eastern Alps during late Tertiary tectonic extrusion. Tectonophysics, 297(1-4), 1-15.

Frisch, W., Kuhlemann, J., Dunkl, I., \& Szekely, B. (2001). The Dachstein paleosurface and the Augenstein Formation in the Northern Calcareous Alps-A mosaic stone in the geomorphological evolution of the Eastern Alps. International Journal of Earth Sciences, 90(3), 500-518.

Froitzheim, N., Plasienka, D., \& Schuster, R. (2008). Alpine tectonics of the Alps and Western Carapathians. In T. McCann (Ed.), The geology of central Europe (Vol. 2, pp. 1141-1232). London: Geological Society of London. https://doi.org/10.1144/ CEV2P.6

Fügenschuh, B., Seward, D., \& Mancktelow, N. (1997). Exhumation in a convergent orogen: The western Tauern window. Terra Nova, 9(5-6), 213-217.

Galbraith, R. F., \& Laslett, G. M. (1993). Statistical models for mixed fission track ages. International Journal of Radiation Applications and Instrumentation. Part D. Nuclear Tracks and Radiation Measurements, 21(4), 459-470.

Genser, J., Cloetingh, S. A. P. L., \& Neubauer, F. (2007). Late orogenic rebound and oblique Alpine convergence: New constraints from subsidence analysis of the Austrian Molasse basin. Global and Planetary Change, 58(1-4), 214-223.

Gleadow, A. J. W. (1981). Fission-track dating methods: What are the real alternatives? Nuclear Tracks, 5(1-2), 3-14.

Grad, M., Brückl, E., Majdanski, M., Behm, M., Guterch, A., \& CELEBRATION 2000 and ALP 2002 Working Groups (2009). Crustal structure of the Eastern Alps and their foreland: Seismic model beneath the CEL10/Alp04 profile and tectonic implications. Geophysical Journal International, 177, 279-295. https://doi.org/10.1111/j.1365-246X.2008.04074.x

Granado, P., Thöny, W., Carrera, N., Gratzer, O., Strauss, P., \& Muñoz, J. (2016). Basement-involved reactivation in foreland fold-andthrust belts: The Alpine-Carpathian junction (Austria). Geological Magazine, 153(5-6), 1110-1135. https://doi.org/10.1017/ S0016756816000066

Gruber, W., \& Sachsenhofer, R. F. (2001). Coal deposition in the Noric depression (Eastern Alps): Raised and low-lying mires in Miocene pull-apart basins. International Journal of Coal Geology, 48(1-2), 89-114.

Grundmann, G., \& Morteani, G. (1985). The young uplift and thermal history of the central Eastern Alps (Austria/Italy), evidence from apatite fission track ages. Jahrbuch der Geologischen Bundesanstalt, 128, 197-216.

Handy, M. R., Schmid, S. M., Bousquet, R., Kissling, E., \& Bernoulli, D. (2010). Reconciling plate-tectonic reconstructions of Alpine Tethys with the geological-geophysical record of spreading and subduction in the Alps. Earth-Science Reviews, 102(3-4), $121-158$.

Heberer, B., Reverman, R. L., Fellin, M. G., Neubauer, F., Dunkl, I., Zattin, M., et al. (2016). Postcollisional cooling history of the Eastern and Southern Alps and its linkage to Adria indentation. International Journal of Earth Sciences, 106(5), 1157-1580.

Hejl, E. (1997). 'Cold spots' during the Cenozoic evolution of the Eastern Alps: Thermochronological interpretation of apatite fission-track data. Tectonophysics, 272, 159-173. https://doi.org/10.1016/s0040-1951(96)00256-9

Hohenegger, J., Rögl, F., Corić, S., Pervesler, P., Lirer, F., Roetzel, R., et al. (2009). The Styrian basin: A key to the middle Miocene (Badenian/Langhian) Central Paratethys transgressions. Austrian Journal of Earth Sciences, 102(1), 102-132.

Hoinkes, G., Koller, F., Rantitsch, G., Dachs, E., Höck, V., Neubauer, F., \& Schuster, R. (1999). Alpine metamorphism of the Eastern Alps. Schweizerische Mineralogische und Petrographische Mitteilungen, 79(1), 155-181.

Hölzel, M., Decker, K., Zámolyi, A., Strauss, P., \& Wagreich, M. (2010). Lower Miocene structural evolution of the central Vienna basin (Austria). Marine and Petroleum Geology, 27(3), 666-681.

Horváth, F., Bada, G., Szafian, P., Tari, G., Adam, A., \& Cloetingh, S. (2006). Formation and deformation of the Pannonian basin: Constraints from observational data. Geological Society, London, Memoirs, 32(1), 191-206.

Hurford, A. J., \& Green, P. F. (1983). Zeta age calibration of fission-track dating. Chemical Geology, 1(4), $285-317$.

Ketcham, R. A. (2005). Forward and inverse modeling of low-temperature thermochronometry data. Reviews in Mineralogy and Geochemistry, 58(1), 275-314.

Ketcham, R. A., Carter, A., Donelick, R. A., Barbarand, J., \& Hurford, A. J. (2007). Improved modeling of fission-track annealing in apatite. American Mineralogist, 92(5-6), 799-810. 
Kipata, M. L., Delvaux, D., Sebagenzi, M. N., Cailteux, J., \& Sintubin, M. (2013). Brittle tectonic and stress field evolution in the Pan-African Lufilian arc and its foreland (Katanga, DRC): From orogenic compression to extensional collapse, transpressional inversion and transition to rifting. Geologica Belgica, 16(1-2), 1-17.

Krenn, K., Harald, F., Aberra, M., \& Johannes, S. (2008). Late Cretaceous exhumation history of an extensional extruding wedge (Graz Paleozoic Nappe Complex, Austria). International Journal of Earth Sciences, 97(6), 1331-1352.

Kuhlemann, J. (2007). Paleogeographic and paleotopographic evolution of the Swiss and Eastern Alps since the Oligocene. Global and Planetary Change, 58(1-4), 224-236.

Kuhlemann, J., Dunkl, I., Brügel, A., Spiegel, C., \& Frisch, W. (2006). From source terrains of the Eastern Alps to the Molasse basin: Detrital record of non-steady-state exhumation. Tectonophysics, 413(3-4), 301-316.

Kuhlemann, J., Frisch, W., Dunkl, I., Szekely, B., \& Spiegel, C. (2001). Miocene shifts of the drainage divide in the Alps and their foreland basin. Zeitschrift für Geomorphologie, 45(2), 239-265.

Kuhlemann, J., Frisch, W., Székely, B., Dunkl, I., \& Kázmér, M. (2002). Post-collisional sediment budget history of the Alps: Tectonic versus climatic control. International Journal of Earth Sciences, 91(5), 818-837.

Kuhlemann, J., \& Kempf, O. (2002). Post-Eocene evolution of the North Alpine foreland basin and its response to Alpine tectonics. Sedimentary Geology, 152, 45-78.

Kurz, W., Wölfler, A., Rabitsch, R., \& Genser, J. (2011). Polyphase movement on the Lavanttal fault zone (Eastern Alps): Reconciling the evidence from different geochronological indicators. Swiss Journal of Geosciences, 104(2), 323-343.

Lee, E. Y., \& Wagreich, M. (2017). Polyphase tectonic subsidence evolution of the Vienna basin inferred from quantitative subsidence analysis of the northern and central parts. International Journal of Earth Sciences (Geologische Rundschau), 106(2), 687-705. https://doi org/10.1007/s00531-016-1329-9

Leever, K. A., Gabrielsen, R. H., Sokoutis, D., \& Willingshofer, E. (2011). The effect of convergence angle on the kinematic evolution of strain partitioning in transpressional brittle wedges: Insight from analog modeling and high-resolution digital image analysis. Tectonics, 30, TC2013. https://doi.org/10.1029/2010TC002823

Legrain, N., Dixon, J., Stüwe, K., von Blanckenburg, F. V., \& Kubik, P. (2015). Post-Miocene landscape rejuvenation at the eastern end of the Alps. Lithosphere, 7(1), 3-13. https://doi.org/10.1130/L391.1

Legrain, N., Stüwe, K., \& Wölfler, A. (2014). Incised relict landscapes in the Eastern Alps. Geomorphology, 221, 124-138.

Linzer, H.-G., Decker, K., Peresson, H., Dell'Mour, R., \& Frisch, W. (2002). Balancing lateral orogenic float of the Eastern Alps. Tectonophysics, 354(3-4), 211-237.

Luth, S. W., \& Willingshofer, E. (2008). Mapping of the post-collisional cooling history of the Eastern Alps. Swiss Journal of Geosciences, $101,207-223$

Matenco, L., \& Radivojević, D. (2012). On the formation and evolution of the Pannonian basin: Constraints derived from the structure of the junction area between the Carpathians and Dinarides. Tectonics, 31, TC6007. https://doi.org/10.1029/ 2012 TC003206

Merten, S. (2011). Thermo-tectonic evolution of a convergent orogen with low-topographic build-up: Exhumation and kinematic patterns in the Romanian Carpathians derived from thermochronology. ( $\mathrm{PhD}$ thesis). Amsterdam: VU University Amsterdam.

Most, P. (2003). Late Alpine cooling histories of tectonic blocks along the central part of the Transalp-Traverse (Inntal-Gadertal): Constraints from geochronology. Tübinger Geowissenschaftliche Arbeiten., 67.

Neubauer, F., Dallmeyer, R. D., Dunkl, I., \& Schirnik, D. (1995). Late Cretaceous exhumation of the metamorphic Gleinalm dome, Eastern Alps: Kinematics, cooling history and sedimentary response in a sinistral wrench corridor. Tectonophysics, 242(1-2), 79-98.

Neubauer, F., Genser, J., \& Handler, R. (2000). The Eastern Alps: Result of a two-stage collision process. Mitteilungen der Österreichischen Geollogischen Gesellschaft, 92(1999), 117-134.

Neubauer, F., \& Unzog, W. (2003). Halfgraben formation in an extruding wedge: The Neogene Waldheimat basin in the Eastern Alps. Neues Jahrbuch für Geologie und Paläontologie ( Abhandlungen), 230(2-3), 277-298.

Peresson, H., \& Decker, K. (1997a). Far-field effect of late Miocene subduction in the eastern Carpathians: E-W compression and inversion of structures in the Alpine-Carpathian-Pannonian region. Tectonics, 16(1), 38-56.

Peresson, H., \& Decker, K. (1997b). The Tertiary dynamics of the northem Eastem Alps (Austria): Changing palaeostresses in a collisional plate boundary. Tectonophysics, 272, 125-157.

Petit, J. P. (1987). Criteria for the sense of movement on fault surfaces in brittle rocks. Journal of Structural Geology, 9(5-6), 597-608

Pischinger, G., Kurz, W., Übleis, M., Egger, M., Fritz, H., Brosch, F. J., \& Stingl, K. (2008). Fault slip analysis in the Koralm Massif (Eastern Alps) and consequences for the final uplift of "cold spots" in Miocene times. Swiss Journal of Geosciences, 101(1), 235-254.

Pomella, H., Klotzli, U., Scholger, R., Stipp, M., \& Fügenschuh, B. (2011). The Northern Giudicarie and the Meran-Mauls fault (Alps, Northern Italy) in the light of new paleomagnetic and geochronological data from boudinaged Eo-/Oligocene tonalites. International Journal of Earth Sciences, 100(8), 1827-1850.

Qorbani, E., Bokelmann, G., \& Bianchi, I. (2015). Slab detachment under the Eastern Alps seen by seismic anisotropy. Earth and Planetary Science Letters, 409, 96-108. https://doi.org/10.1016/j.epsl.2014.10.049

Ratschbacher, L., Frisch, W., Linzer, H. G., \& Merle, O. (1991). Lateral extrusion in the Eastern Alps, part 2: Structural analysis. Tectonics, $10(2), 257-271$

Ratschbacher, L., Merle, O., Davy, P., \& Cobbold, P. (1991). Lateral extrusion in the Eastern Alps, part 1: Boundary conditions and experiments scaled for gravity. Tectonics, 10(2), 245-256.

Reinecker, J. (2000). Stress and deformation: Miocene to present-day tectonics in the Eastern Alps. Tübinger Geowissenschaftliche Arbeiten., 55.

Reinecker, J., \& Lenhardt, W. A. (1999). Present-day stress field and deformation in eastern Austria. International Journal of Earth Sciences, $88(3), 532-550$

Reischenbacher, D., \& Sachsenhofer, R. F. (2013). Basin formation during the post-collisional evolution of the Eastern Alps: The example of the Lavanttal basin. International Journal of Earth Sciences, 102(2), 517-543.

Robl, J., Hergarten, S., \& Stüwe, K. (2008). Morphological analysis of the drainage system in the Eastern Alps. Tectonophysics, 460(1-4), 263-277.

Robl, J., Stüwe, K., Hergarten, S., \& Evans, L. (2008). Extension during continental convergence in the Eastern Alps: The influence of orogen-scale strike-slip faults. Geology, 36, 603-606.

Rosenberg, C. L., Berger, A., Bellahsen, N., \& Bousquet, R. (2015). Relating orogen width to shortening, erosion, and exhumation during Alpine collision. Tectonics, 34, 1306-1328. https://doi.org/10.1002/2014TC003736 
Rosenberg, C. L., Schneider, S., Scharf, A., Bertrand, A., Hammerschmidt, K., Rabaute, A., \& Brun, J.-P. (2018). Relating collisional kinematics to exhumation processes in the Eastern Alps. Earth-Science Reviews, 176, 311-344. https://doi.org/10.1016/j. earscirev.2017.10.013

Sachsenhofer, R. F. (2001). Syn- and post-collisional heat flow in the Cenozoic Eastern Alps. International Journal of Earth Sciences, 90(3), 579-592.

Sachsenhofer, R. F., Dunkl, I., Hasenhüttl, C., \& Jelen, B. (1998). Miocene thermal history of the southwestern margin of the Styrian basin Vitrinite reflectance and fission-track data from the Pohorje/Kozjak area (Slovenia). Tectonophysics, 297(1-4), 17-29.

Sachsenhofer, R. F., Gruber, W., \& Dunkl, I. (2010). Das Miozän der Becken von Leoben und Fohnsdorf. Exkursionsführer PANGEO 2010. Journal of Alpine Geology, 53, 9-38.

Sachsenhofer, R. F., Kogler, A., Polesny, H., Strauss, P., \& Wagreich, M. (2000). The Neogene Fohnsdorf basin: Basin formation and basin inversion during lateral extrusion in the Eastern Alps (Austria). International Journal of Earth Sciences, 89(2), 415-430.

Sachsenhofer, R. F., Lankreijer, A., Cloetingh, S., \& Ebner, F. (1997). Subsidence analysis and quantitative basin modelling in the Styrian basin (Pannonian basin system, Austria). Tectonophysics, 272(2-4), 175-196.

Scharf, A., Handy, M. R., Schmid, S. M., Favaro, S., Sudo, M., Schuster, R., \& Hammerschmidt, K. (2016). Grain-size effects on the closure temperature of white mica in a crustal-scale extensional shear zone-Implications of in-situ 40Ar/39Ar laser-ablation of white mica for dating shearing and cooling (Tauern window, Eastern Alps). Tectonophysics, 674, 210-226. https://doi.org/10.1016/j.tecto.2016.02.014

Schmid, S., Scharf, A., Handy, M. R., \& Rosenberg, C. (2013). The Tauern window (Eastern Alps, Austria): A new tectonic map, with crosssections and a tectonometamorphic synthesis. Swiss Journal of Geosciences, 106(1), 1-32.

Schmid, S. M., Fügenschuh, B., Kissling, E., \& Schuster, R. (2004). Tectonic map and overall architecture of the Alpine orogen. Eclogae Geologicae Helvetiae, 97, 92-117.

Schuster, K., Berka, R., Draganits, E., Frank, W., \& Schuster, R. (2001). Lithologien, Metamorphosegeschichte und tektonischer Bau der kristallinen Einheiten am Alpenostrand. In G. W. Mandl (Ed.), Arbeitstagung 2001 Neuberg a.d. Mürz 3.-7. September (pp. 29-56). Wien: Geologischen Bundesanstalt.

Schuster, R., Nievoll, J., Rupp, C., Ćorić, S., \& Ilickovic, T. (2016). Neogene Sedimente und Landschaftsentwicklung im Umfeld der Kartenblätter GK50 Blatt 103 Kindberg und 135 Birkfeld. In R. Schuster \& T. Knoll (Eds.), Arbeitstagung 2015 der Geologischen Bundesanstalt Geologie der Kartenblätter GK50 ÖK 103 Kindberg und ÖK 135 Birkfeld (pp. 127-143). Vienna: Geologische Bundesanstalt.

Staufenberg, H. (1987). Apatite fission-track evidence for postmetamorphic uplift and cooling history of the Eastern Tauern window and the surrounding Austroalpine (central Eastern Alps). Jahrbuch der Geologischen Bundesanstalt, 586(1985), 571-586.

Steenken, A., Siegesmund, S., Heinrichs, T., \& Fügenschuh, B. (2002). Cooling and exhumation of the Rieserferner Pluton (Eastern Alps, Italy/Austria). International Journal of Earth Sciences, 91, 799-817.

Stöckhert, B., Brix, M. R., Kleinschrodt, R., Hurford, A. J., \& Wirth, R. (1999). Thermochronometry and the microstructures of quartz-A comparison with experimental flow laws and predictions on the temperature of the brittle-plastic transition. Journal of Structural Geology, 21, 351-369

Strauss, P., Wagreich, M., Decker, K., \& Sachsenhofer, R. (2001). Tectonics and sedimentation in the Fohnsdorf-Seckau basin (Miocene, Austria): From a pull-apart basin to a half-graben. International Journal of Earth Sciences, 90(3), 549-559.

Tagami, T., \& Shimada, C. (1996). Natural long-term annealing of the zircon fission track system around a granitic pluton. Journal of Geophysical Research, 101(B4), 8245-8255.

Thöni, M. (1999). A review of geochronological data from the Eastern Alps. Schweizerische Mineralogische und Petrographische Mitteilungen, 79(1), 209-230.

Thöni, M. (2006). Dating eclogite-facies metamorphism in the Eastern Alps-approaches, results, interpretations: A review. Mineralogy and Petrology, 88(1-2), 123-148.

van Gelder, I. E., Willingshofer, E., Andriessen, P. A. M., Schuster, R., \& Sokoutis, D. (2020). Fault slip inversion data from the Mur-Mürz fault, Eastern Alps. GFZ Data Services. https://doi.org/10.5880/fidgeo.2020.003

Van Gelder, I. E., Willingshofer, E., Sokoutis, D., \& Cloetingh, S. A. P. L. (2017). The interplay between subduction and lateral extrusion: A case study for the European Eastern Alps based on analogue models. Earth and Planetary Science Letters, 472, 82-94. https://doi.org/ 10.1016/j.epsl.2017.05.012

Viola, G., Mancktelow, N. S., \& Seward, D. (2001). Late Oligocene-Neogene evolution of Europe-Adria collision: New structural and geochronological evidence from the Giudicarie fault system (Italian Eastern Alps). Tectonics, 20(6), 999-1020.

Wagner, T., Fabel, D., Fiebig, M., Hauselmann, P., Sahy, D., Xu, S., \& Stüwe, K. (2010). Young uplift in the non-glaciated parts of the Eastern Alps. Earth and Planetary Science Letters, 295(1-2), 159-169.

Wagner, T., Fritz, H., Stüwe, K., Nestroy, O., Rodnight, H., Hellstrom, J., \& Benischke, R. (2011). Correlations of cave levels, stream terraces and planation surfaces along the River Mur-Timing of landscape evolution along the eastern margin of the Alps. Geomorphology, 134(1), 62-78.

Willingshofer, E., \& Cloetingh, S. (2003). Present-day lithospheric strength of the Eastern Alps and its relationship to neotectonics Tectonics, 22(6), 1075. https://doi.org/10.1029/2002TC001463

Willingshofer, E., \& Neubauer, F. (2002). Structural evolution of an antiformal window: The Scheiblingkirchen window (Eastern Alps, Austria). Journal of Structural Geology, 24(10), 1603-1618.

Willingshofer, E., Neubauer, F., \& Cloetingh, S. (1999). The significance of Gosau-type basins for the Late Cretaceous tectonic history of the Alpine-Carpathian belt. Physics and Chemistry of the Earth, Part A: Solid Earth and Geodesy, 24(8), 687-695.

Willingshofer, E., \& Sokoutis, D. (2009). Decoupling along plate boundaries: Key variable controlling the mode of deformation and the geometry of collisional mountain belts. Geology, 37(1), 39-42.

Wölfler, A., Dekant, C., Danišík, M., Kurz, W., Dunkl, I., Putiš, M., \& Frisch, W. (2008). Late stage differential exhumation of crustal blocks in the central Eastern Alps: Evidence from fission track and (U-Th)/He thermochronology. Terra Nova, 20(5), 378-384

Wölfler, A., Dekant, C., Frisch, W., Danisik, M., \& Frank, W. (2015). Cretaceous to Miocene cooling of Austroalpine units southeast of the Tauern window (Eastern Alps) constrained by multi-system thermochronometry. Austrian Journal of Earth Sciences, 108(1), $16-33$

Wölfler, A., Kurz, W., Fritz, H., Glotzbach, C., \& Danišík, M. (2016). Late Miocene increasing exhumation rates in the eastern part of the Alps-Implications from low temperature thermochronology. Terra Nova, 28, 297-305. https://doi.org/10.1111/ter.12221

Wölfler, A., Kurz, W., Fritz, H., \& Stüwe, K. (2011). Lateral extrusion in the Eastern Alps revisited: Refining the model by thermochronological, sedimentary, and seismic data. Tectonics, 30, TC4006. https://doi.org/10.1029/2010TC002782

Wölfler, A., Stüwe, K., Danišík, M., \& Evans, N. J. (2012). Low temperature thermochronology in the Eastern Alps: Implications for structural and topographic evolution. Tectonophysics, 541-543(6), 1-18. https://doi.org/10.1016/j.tecto.2012.03.016 
Zattin, M., Bersani, D., \& Carter, A. (2007). Raman microspectroscopy: A non-destructive tool for routine calibration of apatite crystallographic structure for fission-track analyses. Chemical Geology, 240(3-4), 197-204.

Zeilinger, G., Kuhlemann, J., Reinecker, J., Kazmer, M., \& Frisch, W. (1999). The Tamsweg Tertiary in the Lungau region (Austria): Facies and deformation of an intramontane basin. Neues Jahrbuch für Geologie und Paläontologie (Abhandlungen), 214(3), 537-569. 